\title{
AVALIAÇÃO DE QUATRO AGENTES \\ CIMENTANTES, QUANTO ÀS RESISTÊNCIAS AO CISALHAMENTO POR PUNCIONAMENTO, À COMPRESSÃO AXIAL E DIAMETRAL
}

\section{Breno Mont' Alverne Haddade Silva}

Dissertação apresentada à Faculdade de Odontologia de Bauru, Universidade de São Paulo, como parte dos requisitos para a obtenção do título de mestre em Odontologia, área de Dentística Restauradora - opção Materiais Dentários. 


\section{AVALIAÇÃO DE QUATRO AGENTES \\ CIMENTANTES, QUANTO ÀS RESISTÊNCIAS AO \\ CISALHAMENTO POR PUNCIONAMENTO, À \\ COMPRESSÃO AXIAL E DIAMETRAL}

\section{Breno Mont' Alverne Haddade Silva}

Dissertação apresentada à Faculdade de Odontologia de Bauru, Universidade de São Paulo, como parte dos requisitos para a obtenção do título de mestre em

Odontologia, área de Dentística Restauradora - opção Materiais Dentários.

Orientador: Prof. Dr. José Mondelli 


\begin{tabular}{|c|}
\hline SILVA, BRENO MONT' ALVERNE HADDADE \\
Si38a $\quad$ Avaliação de quatro agentes cimentantes, quanto às resistências \\
ao cisalhamento por puncionamento, à compressão axial e diametral / \\
Breno Mont' Alverne Haddade Silva - Bauru, 2007. \\
$69 f$. : il.; $30 \mathrm{~cm}$. \\
Dissertação (Mestrado) - Faculdade de Odontologia de Bauru. \\
Universidade de São Paulo \\
Orientador: Prof. Dr. José Mondelli
\end{tabular}

Autorizo, exclusivamente para fins acadêmicos e científicos, a reprodução total ou parcial desta dissertação, por processos fotocopiadores e outros meios eletrônicos.

\section{ASSINATURA}

Bauru, de de 2007 



\section{Breno Mont' Alverne Haddade Silva}

04 de Setembro de 1979

Belém - PA

Ozorio Mont' Alverne Silva Debora Haddade Silva

$1998-2003$

2003-2004

2005-2007
Nascimento

Filiação

Curso de Graduação em Odontologia Centro Universitário do Pará (CESUPA).

Curso de Especialização em Dentística Restauradora - Fundação Bauruense de Estudos Odontológicos (FUNBEO)

Programa de Pós-Graduação em Mestrado em Dentística Restauradora - opção Materiais Dentários - Faculdade de Odontologia de Bauru - Universidade de São Paulo (FOB-USP). 
"Vi anda debaixo do sol que não é dos ligeiros o prêmio, nem dos valentes, a vitória, nem tampouco dos sábios, o pão, nem ainda dos prudentes a riqueza, nem dos inteligentes, o favor: porém tudo depende do tempo $e$ do acaso"

Eclesiastes 9,11 
Dedico minha vida juntamente com este trabalho a duas pessoas que Deus colocou no meu caminho desde que nasci. Obrigado Pai (Ozorio Mont' Alverne Silva) e Mãe (Debora Haddade Silva). Vocês são e sempre serão importantes para mim.

Dedico a Deus por sempre iluminar meus caminhos, além de me ajudar a buscar pacientemente meus objetivos. Só tenho a agradecer. 


\section{AGRADECIMENTOS PESSOAIS}

Acima de tudo aos meus irmãos, Lulu, Ioioh e Bruno e minha cunhadinha Andréa, obrigado por fazerem parte desta etapa cumprida e por sempre estarem do meu lado em todos os momentos. Lulu, sempre emotiva trabalhadora, dedicada e disposta a fazer de tudo para ajudar; te admiro muito mana. Ioioh, uma inteligência suprema, conheço poucas pessoas com uma cultura tão vasta; é sempre bom falar qualquer assunto contigo. Bruno, você é o cara. Uma tranqüilidade exagerada, uma paciência de monge, um irmão sempre preocupado com a família, sempre querendo ver tudo bem em plena harmonia e Cunhadinha continue fazendo o meu irmão feliz, você entrou na família e sempre será uma pessoa muito especial. Amo vocês!

A Erika Martins Pereira, uma mulher e pessoa maravilhosa que espero conviver o resto da minha vida. Tudo o que você fez e faz por mim tem muito valor, o nosso dia-a-dia profissional, sem dúvida é de luta, de esforço, dedicação, mas acima de tudo, a nossa vida a dois deve sempre ter respeito, carinho, muita felicidade e MUITO AMOR! Obrigado Baixinha!

Ao Prof. Dr. José Mondelli, primeiramente minha admiração, pois é um prazer ver uma pessoa gostar tanto do que faz com tanta dedicação. $O$ senhor terá sempre todo o meu respeito e consideração, pois foi um prazer conviver ao seu lado.

Ao Prof. Dr. César Antunes de Freitas, que sempre ajudou e me acolheu como um grande amigo. Obrigado é pouco por ter tido o prazer da tua companhia e por ter contribuído muito para a minha formação.

Ao Prof. Dr. Paulo Afonso Silveira Franciscone, pois se um dia eu conseguir ter metade da sua tranqüilidade, já me darei por satisfeito. Uma pessoa humana e muito querida com certeza.

Aos meus amigos de Mestrado Cristiane, Fabiane, Ian, Leandro e Márcia. Cada um teve seu papel importante na minha vida. Cris, obrigado pelas festas na sua casa e pelo prazer da sua companhia. Fabiane, uma pessoa simples e maravilhosa da conviver. Ian, a tranqüilidade em pessoa; valeu "Man". Leandro, um carioca marrento, mas gente boa; é bom ter um amigo como você, tanto pessoal quanto profissionalmente. E Márcia, simplesmente uma pessoa especial, amiga, companheira, irmã, que com certeza guardarei para sempre no meu coração. VALEU TURMA! 
Aos meus amigos José Sergio e Fernando, por sempre estarem do meu lado, que bom poder contar com vocês e descobrir a cada dia o quanto vocês são parceiros. Uma amizade sincera e certamente eterna.

As minhas queridas amigas Melanie e Karen, tão diferentes, de comportamentos inversamente proporcionais, mas muito especiais. Obrigado por estarem presentes nos momentos importantes da minha vida aqui em Bauru.

Ao meu grande amigo de Faculdade Diogo Rubim, é muito bom poder ter alguém do meu lado de Belém, que tenho uma enorme consideração, respeito e confiança. Valeu, você é o cara!

Aos meus amigos da especialização, Ricardo, Ney, Mateus, Walmir, Juan, Renata, Marcela (também amigos no Mestrado) Emilia, vocês participaram do meu começo em Bauru e foi muito bom ter conhecido todos.

Aos amigos do Doutorado Renato, Anuradha, Rosana pela ótima convivência e por estarem sempre dispostos a ajudar. Tenho uma admiração muito grande por você Renato, uma pessoa simples, tranqüila e com um conhecimento e um intelecto acima do normal. 


\section{AGRADECIMENTOS AOS PROFESSORES E FUNCIONÁRIOS}

Ao Prof. Dr. Rafael Mondelli, Coordenador do curso de Mestrado em Dentística Restauradora, pela colaboração no meu aprendizado.

Aos Professores doutores Eduardo Batista Franco, Maria Teresa Atta, José Carlos Pereira, Carlos Eduardo Francischone, pelas disciplinas ministradas durante o curso.

Aos Professores Doutores Vinicius Carvalho Porto e Luis Antonio de Assis Taveira, pessoas que considero amigos e tive o prazer de conhecê-los.

Aos funcionários da Dentística: Ângela, Rita, Karen, Beth sempre tão dispostas a ajudar, nunca se opondo a nada e muito menos tendo má vontade para resolver qualquer problema. Com certeza tenho um carinho especial por cada uma. Ao Nelson, que foi um prazer conhecer, uma pessoa tão simples, trabalhadora e sempre disposto a ajudar. A Zuleyka (Zuzu), você é muito especial, sempre correndo e fazendo o que pode.

A Ziley, que hoje tenho como uma grande amiga, tive o prazer de conhecê-la na minha especialização e poder contar com você.

Aos funcionários do Materiais Dentários: Sandrinha, "a faz tudo" do materiais. O que seria da disciplina sem você! Muito obrigado! Ao Alcides, o protético, dentista, polivalente do Materiais, é bom ter você como amigo e profissional. A Lourisvalda (Lou), a funcionária da limpeza que nunca abandonou seu posto do Matérias Dentários. Obrigado pelos inúmeros cafés e coisas gostosas que você fez. Vocês três são muito especiais!

Ao CIP em nome da Dona Neusa, que me ajudou a desenvolver minha pesquisa, confiando em mim para utilizar as instalações dia e noite. 


\section{AGRADECIMENTOS INSTITUCIONAIS}

Ao Conselho Nacional de Desenvolvimento Científico e Tecnológico (CNPQ), pela concessão da bolsa de mestrado.

As empresas DFL e VIGODENT, pelo patrocínio da pesquisa. Sem vocês não teria conseguido de forma simples e dinâmica. Muito Obrigado!

À Faculdade de Odontologia de Bauru, Universidade de São Paulo, na pessoa de seu excelentíssimo Diretor Prof. Dr. Luiz Fernando Pegoraro.

À comissão de Pós-Graduação da Faculdade de Odontologia de Bauru, na pessoa do presidente Prof. Dr. José Carlos Pereira. 


\section{SUMÁRIO}

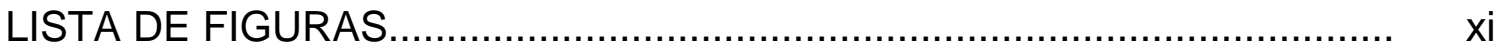

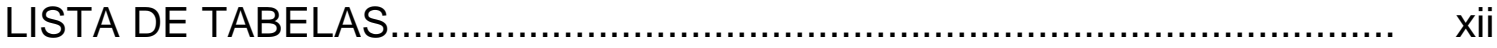

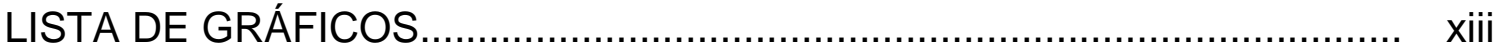

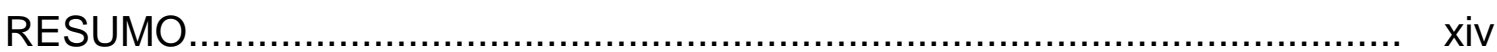

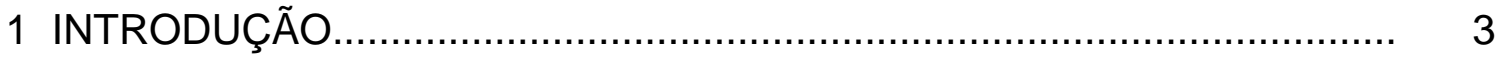

2 REVISÃO DE LITERATURA ....................................................... 9

2.1 Agentes Cimentantes........................................................... 9

2.2 Ensaios Mecânicos............................................................. 12

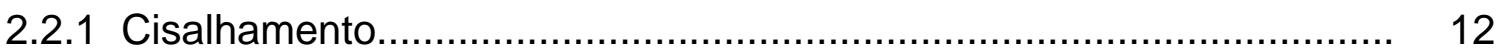

2.2.2 Compressão axial e diametral..................................................... 13

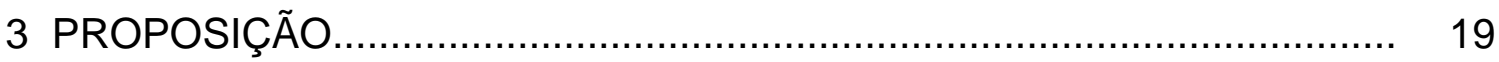

4 MATERIAL E MÉTODOS.......................................................... 23

4.1 Agentes cimentantes analisados e processos de mistura.................... 23

4.2 Confecção dos espécimes para os ensaios mecânicos........................ 25

4.2.1 Espécime para o ensaio de cisalhamento.................................... 26

4.2.2 Espécime para o ensaio de compressão axial e tração diametral........ 28

4.3 Ensaio mecânico de cisalhamento.......................................... 29

4.4 Ensaios mecânicos de compressão axial e diametral.......................... 32

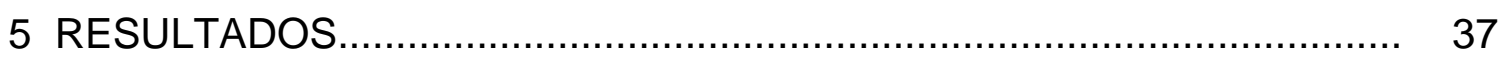

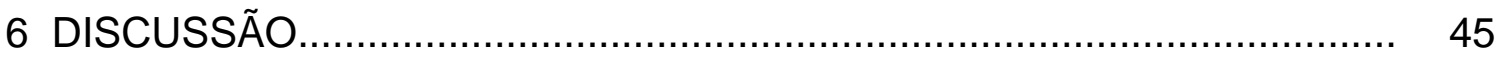

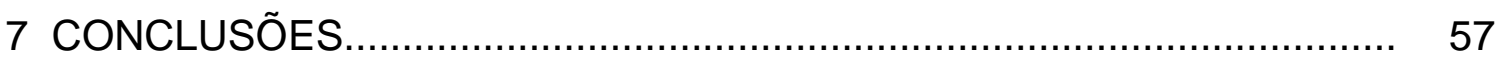

REFERÊNCIAS BIBLIOGRÁFICAS ................................................. 61

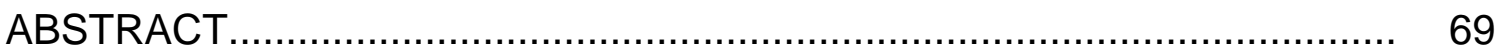




\section{LISTA DE FIGURAS}

Figura 1

Fosfato de zinco.

Figura 2

Fosfato de zinco com cobre.

Figura 3

Ionômero de vidro.

Figura 4

Cimento resinoso.

24

Figura $5 \quad$ Corpos-de-prova em forma de moeda no interior da matrizanel prontos para o ensaio de cisalhamento.

Figura 6

Figura 7

Vista frontal das matrizes bipartidas de PTFE. Em (A) matriz posicionada para a inserção do material. Em (B) Matriz posicionada após a remoção do material.

Figura 8

Inserção do material nos orifícios da matriz montada.

Figura 9

Espécimes 1 e 2 depois de removidos da matriz de PTFE..

Figura 10 Dispositivo posicionado na EMIC pronta para o ensaio. Em (A) corpo do dispositivo. Em (B) Parte superior do puncionador. Em (B1) ponta ativa do puncionador.

Figura 11 Dispositivo posicionado na EMIC pronta para o ensaio. Em

(A) Base superior da EMIC acoplada a célula de carga. Em

(B) Base inferior da EMIC

Figura 12 Corpo-de-prova no interior da matriz antes e após ensaio. (A) Matriz pronta para a inserção do material. (B) Corpode-prova após puncionamento

Figuras 13 e14 Momento do ensaio de compressão axial antes e após a ruptura.

Figuras 15 e16 Momento do ensaio de tração diametral e padrão de ruptura dos espécimes. 


\section{LISTA DE TABELAS}

Tabela 1 Produtos analisados no experimento.....................................

Tabela 2 Médias obtidas com espécimes dos quatro agentes cimentantes para o ensaio de cisalhamento em MPa nos períodos de 1 e 24 horas.

Tabela 3 Médias obtidas dos espécimes dos quatro agentes cimentantes para o ensaio de compressão axial em MPa, nos períodos de 1 e 24 horas.

Tabela 4 Médias obtidas dos espécimes dos quatro agentes cimentantes para o ensaio de tração diametral em MPa, nos períodos de 1 e 24 horas. 


\section{LISTA DE GRÁFICOS}

Gráfico 1 Resistência ao cisalhamento (valores em $\mathrm{MPa}$ ) dos agentes cimentantes em dois períodos diferentes......

Gráfico 2 Resistência à compressão (valores em MPa) dos agentes cimentantes em diferentes períodos.

Gráfico 3 Resistência à Tração Diametral (valores em MPa) dos agentes cimentantes em diferentes períodos....................... 


\section{RESUMO}

Os agentes cimentantes são utilizados, rotineiramente, como meio de fixação para restaurações dentárias e responsáveis por preencher a interface entre o dente e uma restauração, por isso devem apresentar propriedades mecânicas satisfatórias, a fim de suportar os esforços mastigatórios e as cargas oclusais presentes no meio bucal. Sendo assim, o objetivo deste trabalho foi avaliar quatro agentes cimentantes (um fosfato de zinco, um fosfato de zinco com cobre, um ionômero de vidro e um cimento resinoso), em relação às resistências ao cisalhamento por puncionamento, à compressão axial e diametral. Para o ensaio de cisalhamento foram confeccionados espécimes em uma matriz em forma de anel com dimensões de $14 \mathrm{~mm}$ de diâmetro interno e $1,5 \mathrm{~mm}$ de altura que permitia obter um disco ou moeda dos materiais com essas dimensões a qual foi acoplada em um dispositivo próprio para o teste. Já para o ensaio de compressão axial foram seguidas as normas da "ADA n96" e "ISO 9917:1(E) cujo espécime é de formato cilíndrico com dimensões de $6 \mathrm{~mm}$ de altura por $4 \mathrm{~mm}$ de diâmetro. Mesmo não apresentando normas específicas para agentes cimentantes, o ensaio de tração diametral seguiu as dimensões do espécime para o ensaio de compressão. Foram confeccionados 10 espécimes de cada material para os respectivos ensaios, analisados nos períodos de 1 e 24 horas. Os resultados foram tratados estatisticamente com a Análise de Variância a dois critérios (ANOVA), seguido do teste comparativo de tukey com $p<0,05$. O agente cimentante que apresentou os valores mais altos de resistência foi o cimento resinoso para os três testes realizados e o cimento de ionômero de vidro apresentou os valores mais baixos de resistência dentre todos os materiais analisados, juntamente com os diferentes períodos.

Palavras-chaves: Propriedades mecânicas. Agentes cimentantes. Teste de Resistência. 
INTRODUÇÃO 



\section{INTRODUÇÃO}

As restaurações indiretas necessitam de um agente cimentante como meio de fixação ao dente. Dentre suas principais funções, os cimentos são utilizados para preencher as discrepâncias de adaptação entre a restauração e o remanescente dentário e favorecer a retenção friccional entre ambos, resultando em um procedimento com bom vedamento de margens e resistência à remoção e/ou deslocamento (ERGIN; GEMALMAZ ${ }^{11}$, 2002, DE LA MACORRA; PRADÍES ${ }^{12}$, 2002, NICHOLSON; MCKENZIE ${ }^{18}, 1999$, SILVA E SOUZA ${ }^{40}$ et al. 2001).

Caso a cimentação de uma restauração seja mal realizada, discrepâncias marginais e microinfiltração podem ocasionar o surgimento de possíveis doenças periodontais, cárie secundária, sensibilidade pulpar e necrose, além de problemas como manchamento ou descoloração marginal da estrutura dentária (ATTAR; TAM; $\left.\mathrm{MCCOMB}^{3}, 2003\right)$.

A escolha de um agente cimentante vai depender da situação clínica do material que é feito a restauração, combinada com as propriedades físicas, biológicas e de manipulação do material (ATTAR, TAM, MCCOMB ${ }^{3}$, 2003).

Um agente cimentante ideal deve resistir aos esforços mastigatórios promovidos pelas cargas funcionais, que ocorrem ao longo da vida útil da restauração. A integridade dos cimentos deve ser mantida durante a transferência do estresse entre a restauração e a estrutura dentária. Com isso propriedades como resistência, solubilidade e resistência adesiva são analisadas in vitro, de acordo com as normas específicas da ADA e ISO, onde se busca a avaliação da qualidade e desempenho clínico do agente cimentante (LI; WHITE ${ }^{22}$, 1999, ROSENSTIEL; LAND; CRISPIN $\left.{ }^{36}, 1998\right)$.

Os principais agentes cimentantes utilizados para fixação de restaurações unitárias ou múltiplas, disponíveis no mercado nacional são o fosfato de zinco, o óxido de zinco e eugenol, o policarboxilato de zinco, o ionômero de vidro, o ionômero de vidro modificado por resina, o compômero e o cimento resinoso (ANUSAVICE, $\mathrm{K}^{2}$. 2005, DE LA MACORRA; PRADÍES ${ }^{11}$ 2002, FLEMING; MARQUIS; SHORTALL ${ }^{13}, 1999$, MONDELLI ET AL. ${ }^{25}, 1994$, NICHOLSON; MCKENZIE $\left.{ }^{28}, 1999\right)$. 
O cimento de fosfato de zinco, utilizado há mais de 90 anos, é o agente cimentante mais antigo e mais usado como meio de fixação de restaurações indiretas na Odontologia. Sempre foi amplamente pesquisado, principalmente quanto às suas propriedades físicas e mecânicas, as quais comprovam sua eficiência para tal procedimento. Apresenta vantagens bastante favoráveis quando manipulado de forma correta, além de ser um material de baixo custo (ERGIN; GEMALMAZ ${ }^{12}$ 2002, FLEMING; MARQUIS; SHORTALL ${ }^{13} 1986$, MARTINS $^{23}, 1999$; SILVA E SOUZA et al. $\left..^{40}, 2001\right)$.

De acordo com FOLEY; EVANS; LLOYD; BLACKWELL ${ }^{14}$ EM 2001, o fosfato de zinco com adição de cobre surgiu, com a característica de ser provavelmente um agente cariostático, devido à presença de íons de cobre na sua composição. Este material teria como principal função, promover uma redução na colonização de bactérias, pois suas outras características seriam comuns às do cimento de fosfato de zinco convencional.

O cimento de ionômero de vidro é outro agente cimentante presente no mercado odontológico bastante difundido por sua aplicação em vários procedimentos clínicos, sendo um material amplamente utilizado em coroas protéticas, pinos intracanal metálicos ou não. Como características favoráveis apresentam, adesão químico, liberação de flúor, biocompatibilidade e melhoria nas características manipulativas (ALGERA ET AL ${ }^{1}, 2006$, ERGIN; GEMALMAZ ${ }^{12}, 2002$, NAVARRO; PASCOTTO ${ }^{27}$, 1998; SILVA E SOUZA ET AL. ${ }^{40}, 2001 ;$ ).

Os materiais de fixação evoluíram ao longo do tempo e, com o surgimento dos cimentos resinosos, problemas como resistência à união e ao desgaste na fixação de restaurações tanto de porcelana quanto de resina composta puderam ser contornados. Os cimentos resinosos apresentam-se disponíveis no mercado odontológico em três formas de polimerização: química, fotoativada e dupla polimerização. (DE LA MACORRA; PRADÍES ${ }^{11}$, 2002, ERGIN; GEMALMAZ ${ }^{12}$ 2002).

A evolução dos agentes cimentantes fez com que a busca por encontrar um material ideal para os procedimentos de cimentação promovesse maior número de pesquisas relacionadas ao assunto. Dessa forma, um dos métodos de se avaliar a eficiência ou não dos cimentos é por meio de suas propriedades mecânicas, que visam determinar o valor das tensões que eles suportam, por exemplo, resistência ao cisalhamento, à compressão axial e diametral, transmitidas a eles por meio das 
restaurações pela ação das cargas mastigatórias (ANUSAVICE², 2005 , CRAIG; POWERS ${ }^{10}, 2004$, PIWOWARCZYK, A; LAUER, HC ${ }^{31}, 2003$ WHITE; YU $\left.{ }^{44}, 1993\right)$. 
REVISÃO DE LITERATURA 



\section{REVISÃO DE LITERATURA}

\section{1 - Agentes cimentantes}

O cimento de fosfato de zinco, desenvolvido no final do século XIX e início do século $X X$, ainda é, amplamente utilizado na odontologia. A técnica de manipulação do fosfato não foi alterada ao longo dos anos, o que implica em dizer que diversas pesquisas realizadas com este cimento, quanto as suas propriedades mecânicas, biológicas e químicas, fez com que este material apresentasse o mesmo padrão de cimentação (GORODOVSKY, S; ZIDAN, O ${ }^{17}$, 1992, NICHOLSON; MCKENZIE $^{28}$, 1999, SMITH ${ }^{41}$, 1983). Devido a sua larga utilização nos procedimentos odontológicos, o fosfato de zinco é considerado o agente cimentante padrão de comparação entre os demais cimentos presentes no mercado odontológico (ANUSAVICE, K². 2005, CHARLTON ${ }^{8}, 2006$, CIARELLI; ELIAS; NAVARRO; CARVALHO $\left.{ }^{9}, 2001\right)$.

A cimentação de incrustações, coroas, pontes fixas, pinos e facetas, bandas ortodônticas e a utilização como base cavitária são algumas das indicações clássicas desse cimento, apesar de hoje em dia este material não ser mais utilizado como base sob restaurações. Como vantagens, o fosfato quando comparado a outros cimentos apresenta uma técnica de mistura menos crítica, caso seja seguido o padrão de manipulação do material. Entretanto, como desvantagens, incluem-se irritação pulpar, ausência de ação antibacteriana, friabilidade, falta de adesão e solubilidade em ácidos (CHARLTON ${ }^{8}, 2006$, LEWIS; BUURGESS; GRAY ${ }^{21}, 1992$ SMITH $^{41}$, 1983).

Um cimento de fosfato de zinco pouco conhecido do mercado brasileiro, que surgiu por volta de 1892, e é utilizado e conhecido no mercado americano é o fosfato de zinco com cobre. Este material apresenta-se disponível em três colorações: branco, vermelho e preto. Na sua composição apenas ao pó é adicionado o cobre, permanecendo a composição do líquido semelhante ao do fosfato convencional. Há poucas evidências quanto as vantagens desse material, mas a literatura descreve a ação antibacteriana do cobre como sendo a principal vantagem (FOLEY; EVANS; LLOYD; BLACKWELL ${ }^{14}, 2001$, FRASER $^{15}$, 2004). Este 
cimento, segundo o fabricante, está indicado tanto para cimentação de restaurações indiretas, quanto para proteções pulpares (FRASER ${ }^{15}$, 2004).

Por volta de 1950 foram desenvolvidos agentes resinosos para cimentação à base de polimetilmetacrilato de metila. Este cimento resinoso foi desenvolvido para o uso de cimentação de coroas e pontes fixas de cerâmica e resina, fixação de braquetes ortodônticos. Inicialmente, apresentaram propriedades físicas insatisfatórias, além de uma alta contração de polimerização e microinfiltração devido à pequena quantidade de carga presente nas partículas (ANUSAVICE, $\mathrm{K}^{2}$, 2005). Este material, na época, não se tornou popular para a técnica de cimentação. (GORODOVSKY, S; ZIDAN, O ${ }^{17}, 1992$ )

Com isso, surgiram os cimentos a base de Bis-GMA, um monômero resinoso descoberto por Bowen na década de 60, que era disponível, na forma de um pó e um líquido ou dividido em duas pastas. Todos esses materiais tomavam presa por um mecanismo químico de polimerização, mas a manipulação por ser diferente dos cimentos convencionais dificultava a sua utilização. Outro problema inicial, também estava relacionado à irritação tecidual devido à presença de monômero residual, dessa forma, o uso deste material era mais limitado ao esmalte dentário'(CHARLTON ${ }^{8}, 2004$, SMITH $\left.^{41}, 1983\right)$.

Os cimentos resinosos evoluíram com o passar dos anos apresentando uma maior quantidade de partículas de carga e melhores propriedades físicas. O cimento resinoso se divide em fotopolimerizáveis, quimicamente ativados e com dupla polimerização. Como vantagens, este material apresenta alta resistência à compressão e baixa solubilidade.(PIWOWARCZYK, A; LAUER, HC ${ }^{31}$, 2003). Como desvantagens, é irritante pulpar, além de promover uma alta espessura de película'(CHARLTON ${ }^{8}, 2004$, PLATT $\left.^{32}, 1999\right)$.

O estudo de PRAKKI; CARVALHO ${ }^{34}$ em 2001 abordou uma revisão sobre os cimentos resinosos de dupla polimerização, com suas características e considerações clínicas, quanto à utilização deste material para procedimento odontológico. A indicação do cimento resinoso de dupla polimerização recai sob restaurações estéticas, devido estes materiais permitirem a passagem de luz, que dá início à reação de polimerização e em seguida a reação química complementa as regiões onde a luz não consegue alcançar. Os cimentos resinosos duais apresentam após $24 \mathrm{~h}$ da sua polimerização um aumento significativo na resistência de união, mas foi observado que após 10 min os resultados quanto à resistência à união já 
são relativamente altos quando comparados a outros cimentos resinosos. Este cimento apresenta grandes vantagens, como o controle do tempo de trabalho, conversão completa do cimento e melhor relaxamento do estresse causados pelos efeitos da contração de polimerização e deve-se ter cuidado, quanto à utilização do material principalmente em relação à umidade, fotoativação adequada do material, proteção do remanescente dental e cuidados com esforços mastigatórios nas primeiras 24 horas após a cimentação.

Nenhum desses materiais até então possuíam adesão satisfatória ao esmalte e a dentina, o que levou, em meados da década de 60, ao desenvolvimento de cimentos à base de polímeros orgânicos ácidos e íons de metal. Na busca por um agente cimentante que pudesse aderir fortemente à estrutura dentária foi desenvolvido o primeiro cimento dental adesivo polimerizado quimicamente originado do óxido de zinco e uma solução aquosa de ácido denominado de policarboxilato de zinco (ANUSAVICE ${ }^{2}, 2005$, CHARLTON $^{8}, 2006$, CIARELLI; ELIAS; NAVARRO CARVALHO ${ }^{9}, 2001$, SANTOS; STEAGALL; SILVEIRA ${ }^{39}, 1978$, SMITH $^{41}$, 1983).

Em 1972 foi anunciado o surgimento do cimento de ionômero de vidro em um artigo publicado por Wilson e Kent na "British Dental Journal". Este material apresentou uma formulação da mistura do cimento de silicato e o cimento de policarboxilato, esperando a obtenção das características positivas desses dois materiais. Inicialmente este cimento foi designado para restaurações estéticas de classes III e V. Em virtude da adesão à estrutura dentária e seu potencial de prevenir cárie, os ionômeros de vidro passaram a ser utilizados como agentes de cimentação, adesivos para colagem de braquetes, selantes de fóssulas e fissuras, forramentos e bases, núcleos de preenchimento e como restaurações intermediárias (ANUSAVICE $^{2}, \quad 2005, \quad$ KLEVERLAAN; VAN DUINEN; FEILZER ${ }^{18}, 2004$ GORODOVSKY, ZIDAN $\left.{ }^{15}, 1992\right)$. Como vantagens apresentam, liberação de flúor, potencial adesivo as estruturas dentárias satisfatório e coeficiente de expansão térmica semelhante a estrutura dentária. Como desvantagens, o baixo $\mathrm{pH}$, baixa resistência ao desgaste, o tempo de trabalho curto, sensibilidade à umidade e possível irritação pulpar. (CHARLTON ${ }^{8}, 2006$, GERDULO ET AL ${ }^{16}, 1995$ KLEVERLAAN; VAN DUINEN; FEILZER ${ }^{18}, 2004$, SMITH $\left.^{41}, 1983\right)$.

Logo em seguida, os cimentos de ionômero de vidro modificado por resina e os compômeros foram desenvolvidos com o intuito de associar as 
características favoráveis do ionômero de vidro e a resina composta (NICHOLSON; MCKENZIE $\left.{ }^{28}, 1999\right)$.

\section{2 - Ensaios mecânicos}

A tensão é medida pela força ou carga aplicada pela área de secção transversal de um corpo-de-prova resultante da ação sobre um corpo sólido. Existem diversos tipos de tensões desenvolvidas, que variam com a natureza das forças aplicadas e o formato do objeto analisado. Elas podem ser tensões de cisalhamento, compressão e tração (ANUSAVICE ${ }^{2}, 2005$, CRAIG; POWERS $^{10}, 2004$ VIEIRA $^{43}$, 1965).

\subsection{1 - Cisalhamento}

A tensão de cisalhamento se define como a tendência de resistir ao deslizamento de uma parte de um corpo sobre outro e é calculada pela divisão da força aplicada pela área paralela à direção da força (ANUSAVICE², 2005, CRAIG; POWERS $^{10}, 2004$ VIEIRA $\left.^{43}, 1965\right)$.

A resistência ao cisalhamento é importante no estudo da interface entre dois materiais. Um método eficaz para avaliar a resistência ao cisalhamento é o "punch" ou "push-out", no qual a carga axial é aplicada para deslocar um material através de outro. O que se pode afirmar é que a resistência medida por meio desse teste não é considerada cisalhamento propriamente dito, e que os resultados obtidos entre os diferentes trabalhos, podem divergir devido à diferença nas dimensões dos espécimes (MONDELLI ET $A L^{25}$, 1994, NOMOTO; CARRICK; McCABE ${ }^{29}, 2001$, ROYDHOUSE; LEWIS ${ }^{37}, 1969$, SMITH; COOPER $\left.{ }^{42}, 1974,\right)$.

O teste de resistência ao cisalhamento por puncionamento, primeiramente, foi descrito por ROYDHOUSE em $1970^{37}$, como um teste designado a comparar restaurações, tecidos e materiais interpostos em camadas para avaliar a integridade e a resistência, por meio de espécimes em formato de discos pequenos. O método proposto de avaliação era simples e confiável, determinando a possibilidade de diferenciação entre os materiais testados, alem de identificar os efeitos da variação da manipulação dos mesmos (MOUNT, MAKINSON; PETERS ${ }^{26}$, 1996, ROYDHOUSE $\left.{ }^{37}, 1970\right)$. 
Outro método para avaliar a resistência ao cisalhamento por puncionamento foi proposto por SMITH, COOPER ${ }^{42}$ EM 1974, utilizando um dispositivo de micro-puncionamento apresentou várias desvantagens teóricas e práticas, como por exemplo o formato do espécime que devia estar em um plano único, bem posicionado, a fim de evitar qualquer deslocamento, além da fricção entre o pino e o dispositivo do espécime que é um fator constante para a realização do ensaio.

SANTOS; STEAGALL; SILVEIRA ${ }^{39}$ em 1978 realizaram o teste de cisalhamento por puncionamento utilizando o dispositivo semelhante ao de Taylor e Margettis, onde os espécimes foram confeccionados em duas diferentes matrizes, de formato circular e espessura de $1,5 \mathrm{~mm}$, sendo uma de aço e a outra de nylon.

Segundo CIARELLI; ELIAS; NAVARRO; CARVALHO ${ }^{9}$ em 2001, o teste de resistência ao cisalhamento é simples, sendo uma método bem efetivo para testar a resistência coesiva de materiais sólidos. Os autores relatam ainda que uma das vantagens desse teste é a quantidade de material necessária para o preparo dos espécimes menor dos que os testes mecânicos convencionais.

\subsection{2 - Ensaio de compressão axial e diametral}

Quando um corpo é colocado sob a ação de uma carga a tendência é de que o mesmo seja comprimido ou encurtado, dessa forma, a resistência interna a esta carga é denominada tensão de compressão axial (ANUSAVICE ${ }^{2}, 2005$, CRAIG; POWERS $^{10}, 2004$, VIEIRA $\left.^{43}, 1965\right)$.

A compressão representa uma das propriedades mais importantes frente aos esforços mastigatórios e os materiais dentários. A resistência à compressão é uma propriedade mecânica bastante avaliada in vitro, para a análise dos agentes cimentantes (KUMBULOGLU; LASSILA; USER; VALLITTU ${ }^{19}$, 2004, LI; WHITE ${ }^{22}$, 1999).

Diversos trabalhos, que analisam as propriedades mecânicas de resistência à compressão, utilizam dois métodos experimentais, baseados especificamente em duas Normas estabelecidas pela "American Dental Association n 96" e "International Organization of Standardization 9917-1:(E) para os agentes cimentantes". 
Antes da década de 90 as Normas da "ADA" e "ISO" seguiam padrões diferentes, quanto às dimensões dos corpos-de-prova utilizados para os ensaios mecânicos com relação à proporção altura e diâmetro, pois a "ADA" seguia um padrão de espécime com proporção altura/diâmetro 2:1, com dimensões de $12 \mathrm{~mm}$ de altura por 6 de diâmetro e a ISO seguia a proporção de 1,5:1 com dimensões de $6 \mathrm{~mm}$ de altura por $4 \mathrm{~mm}$ de diâmetro, o que impossibilitava em alguns estudos, a comparação exata dos valores de resistência à compressão com relação aos agentes cimentantes (FLEMING; MARQUIS; SHORTALL ${ }^{13}, 1999$, MCCOMB; SIRIKO; BROWN ${ }^{24}, 1984$, PRENTICE; TYAS; BURROW ${ }^{35}, 2005$ SHANE; YU ${ }^{44}$, 1993).

O cuidado ao comparar estes resultados deve ser criterioso, pois a carga necessária de ruptura e área transversal do espécime são importantes para o cálculo da resistência à compressão, como citado anteriormente. O que implica dizer que a comparação dos diversos artigos publicados na odontologia só devem ser realizados caso tenha sido seguido os mesmos padrões estabelecidos para o teste mecânico (FLEMING; MARQUIS; SHORTALL ${ }^{13}$, 1999, PRENTICE; TYAS; BURROW $^{35}, 2005$, VIEIRA $^{43}$, 1965).

Qualquer diferença quanto ao tipo de agente cimentante, forma de manipulação, proporcionamento, tipo de matriz, períodos de avaliação, armazenamento do espécime, temperatura do ambiente e umidade, tipo de máquina de ensaio juntamente com a velocidade de regulagem da máquina podem influenciar para a obtenção de um determinado valor de resistência à compressão para os agentes cimentantes (LEVARTOVSKY; KUYINU; GEORGESCU; GOLDSTEIN²0, 1994, LEWIS; BURGESS; GRAY ${ }^{21}, 1992$, NICHOLSON; MCKENZIE $\left.^{28}, 1999\right)$.

O ensaio de compressão diametral é definido como uma carga compressiva em um corpo-de-prova de formato cilíndrico distribuída ao longo da lateral do espécime produzindo como se fosse uma tensão de tração perpendicular ao plano vertical que passa pelo centro do cilindro. Devido ao espécime, após sofrer ruptura dividir-se em duas partes iguais, o ensaio ficou conhecido internacionalmente também, como tração diametral' (ANUSAVICE ${ }^{2}, 2005$, CARNEIRO; BARCELLOS ${ }^{5}$, 1949).

Este tipo de teste é realizado somente em materiais que possuam predominantemente deformação elástica e pouca ou nenhuma deformação plástica, o que sugere um resultado não confiável quando a fratura de um corpo-de-prova se 
fragmenta em vários pedaços ao invés de se dividir em duas partes. É um ensaio simples de ser realizado, além de fornecer uma reprodução bem satisfatória dos resultados (ANUSAVICE ${ }^{2}, 2005$, CEFALY ET AL ${ }^{6} ; 2003$ )

Este ensaio se diferença da compressão axial, apenas quanto ao posicionamento do corpo-de-prova, pois o espécime confeccionado para avaliação de ambos os ensaios é de formato cilíndrico. Este teste mecânico passou a ser bastante executado, principalmente para os materiais friáveis da odontologia (CEFALY, VALARELLI, SEABRA, MONDELLI, NAVARRO ${ }^{7}, 2001$ ).

Vários artigos que avaliam a resistência à compressão axial, também, analisam a tração diametral por considerar que estas forças atuam de forma complexa no esforço mastigatório (MONDELLI; MARTINS; STEAGALL; NAVARRO ${ }^{25}$, 1994, PALMA ET AL ${ }^{30}, 1994$, WHITE; YU ${ }^{44}$, 1993).

Não há um padrão de confecção dos espécimes para o ensaio de tração diametral com relação aos agentes cimentantes, mas o que se segue é o padrão dos corpos-de-prova dos ensaios de compressão.

O que geralmente se encontra nos trabalhos da literatura quando a resistência à compressão e tração diametral são analisadas, no mesmo artigo, são espécimes de dimensões diferentes ou iguais, mas com a mesma proporção altura/diâmetro (GERDULLO; NAKAMURA; SUGA; NAVARRO ${ }^{16}$, 1995, LEVARTOSVKY, KUIYNU; GEORGESCU; GOLDSTEIN ${ }^{20}$, 1994, MONDELLI; MARTINS; STEAGALL; NAVARRO ${ }^{25}$, 1994, PALMA ET AL ${ }^{30}$ em 1994, POWERS; FARAH; CRAIG ${ }^{33}, 1976$, PRENTICE; TYAS; BURROW ${ }^{35}$, 2005). 

PROPOSIÇÃO 

No presente estudo, o objetivo foi analisar quatro tipos de agentes cimentantes (fosfato de zinco convencional, fosfato de zinco com adição de cobre, um ionômero de vidro e resinoso), quanto às resistências ao cisalhamento por puncionamento, à compressão axial e à ou tração diametral, em dois períodos de tempo, de 1hora e 24 horas após a confecção dos espécimes. 
MATERIAL E MÉTODOS 



\section{MATERIAL E MÉTODOS}

Inicialmente serão identificados os agentes cimentantes aqui estudados, e abordadas considerações a respeito do processo de mistura dos componentes de cada um. Em seguida, será descrita individualmente a confecção dos espécimes dos ensaios de cisalhamento por puncionamento e compressão axial e diametral. Finalmente, serão descritos o ensaio de cisalhamento, assim como os ensaios de compressão axial e diametral.

\section{1 - Agentes cimentantes analisados e processos de mistura}

Os quatro produtos analisados constam da tabela 1 (nome, respectivos fabricantes) e estão ilustrados pelas figuras 1 a 4.

Tabela 1 - Produtos analisados no experimento

\begin{tabular}{l|l|l}
\multicolumn{1}{c|}{ Produto } & \multicolumn{1}{c}{ Nome } & \multicolumn{1}{c}{ Fabricante } \\
\hline Fosfato de zinco & Cimento de zinco & S. S. White, Rio de Janeiro, RJ, \\
\hline $\begin{array}{l}\text { Fosfato de zinco com } \\
\text { cobre }\end{array}$ & $\begin{array}{l}\text { Red Copper Zinc Phosphate } \\
\text { Cement }\end{array}$ & $\begin{array}{l}\text { Cooley \& Cooley Ltd. Houston - } \\
\text { TX, EUA }\end{array}$ \\
\hline lonômero de vidro & Vitro cem & DFL, Rio de Janeiro, RJ, \\
\hline Cimento Resinoso & Fill Magic Dual Cement & Vigodent, Rio de Janeiro, RJ,
\end{tabular}




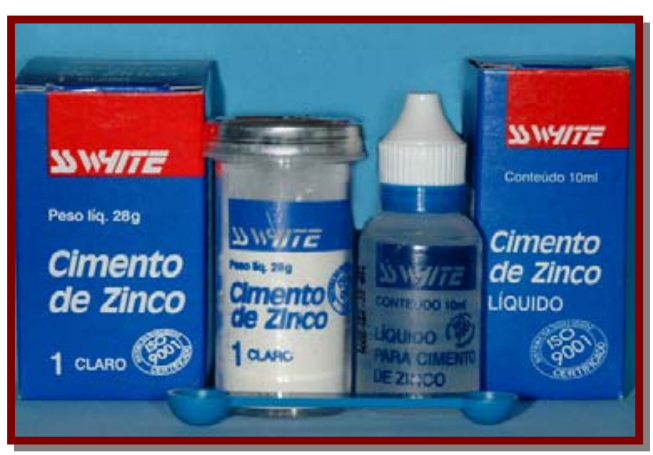

Figura 1 - fosfato de zinco

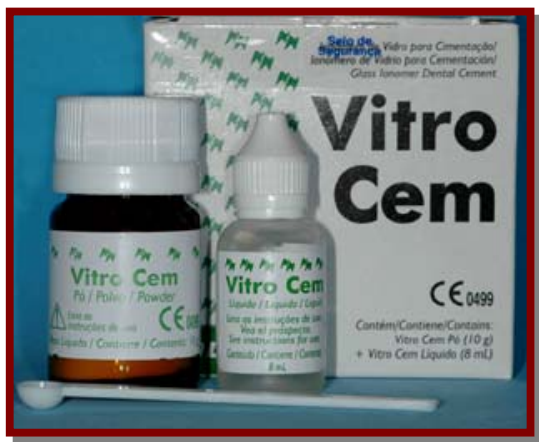

Figura 3 - ionômero de vidro

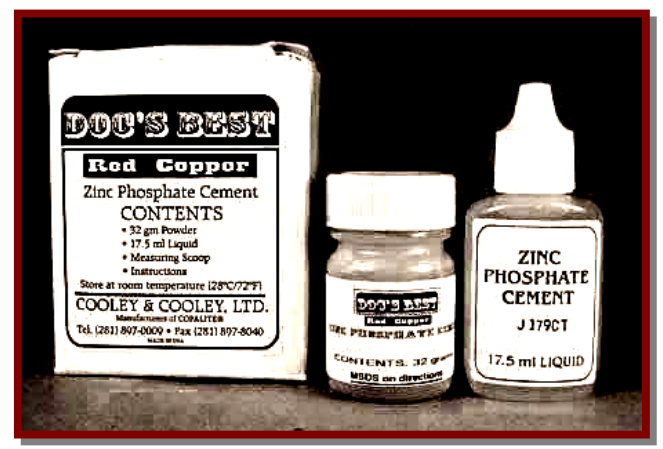

Figura 2 - fosfato de zinco com cobre

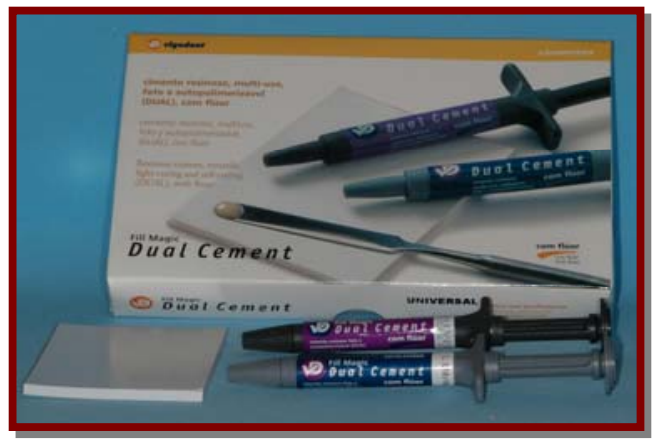

Figura 4 - Cimento resinoso

Todos os cimentos utilizados seguiram as recomendações dos seus respectivos fabricantes quanto ao proporcionamento, sendo que para cada material foi determinada a medição em peso com a utilização de uma balança analítica, obtendo a média a ser utilizada para cada material, após cinco medições, a fim de obter uma padronização para a confecção de todos os espécimes.

O fosfato de zinco foi proporcionado em peso com uma dosagem do pó $(0,3614 \mathrm{~g})$ e 4 gotas de liquido $(0,3021 \mathrm{~g})$, divididos em 6 partes sendo, 1/16, 1/16, 1/8, durante $10 \mathrm{~s}$ cada $1 / 4,1 / 4$, durante $15 \mathrm{~s}, 1 / 4$ durante $30 \mathrm{~s}$, totalizando um tempo de mistura de 1 min e $30 \mathrm{~s}$.

O fosfato de zinco com cobre foi utilizado com o líquido do cimento de fosfato de zinco da S.S. White, com proporção em peso de $(0,2432)$ de pó e 4 gotas de líquido $(0,3021)$ divididos e misturados de forma semelhante ao fosfato convencional.

Para o cimento de ionômero de vidro, a proporção em peso do pó e do líquido $(0,1376 / 0,1275)$ foi representado pelo medidor do pó e 2 gotas do líquido. 0 
material foi misturado com uma espátula de plástico e dividido em duas partes iguais num tempo total de trabalho de $20 \mathrm{~s}$.

Após cada material ser inserido na respectiva matriz, aguardava-se 20 minutos para a remoção dos espécimes, tempo este determinado pelas próprias condições ambientes que retardaram a presa final.

Para evitar incorporação de umidade e causar menor resistência nos corpos-de-prova de ionômero de vidro, após os 20 min de espera para a remoção foi aplicado um verniz protetor nos seus primeiros minutos de idade, por todos os lados do espécime.

O cimento resinoso é representado por duas pastas, sendo uma catalisadora e a outra base, e para a pesagem deste material foi considerado, a quantidade necessária em proporções iguais em peso para ambas as pastas de acordo com as dimensões das matrizes. Após a mistura das pastas foi realizada a polimerização do material durante $40 \mathrm{~s}$ em cada lado da matriz sob luz direta, de um fotopolimerizador do tipo convencional (lâmpada halógena - Ultralux-Dabi Atlante), e somente após 30 minutos o espécime era removido da matriz.

\section{2 - Confecção dos espécimes para os ensaios mecânicos}

Todos os procedimentos envolvendo a confecção de espécimes foram efetuados em ambiente com temperatura de $23 \pm 1^{\circ} \mathrm{C}$ e umidade relativa do ar de $50 \pm 10 \%$.

A confecção dos espécimes para todos os ensaios exigiu a utilização de materiais em comum, que consistiram de: uma placa de vidro de espessura média para a colocação dos agentes cimentantes; 4 placas de vidro de espessura fina para a preensão dos cimentos contra as matrizes interpostos entre tiras de poliéster; uma espátula $n^{\circ} 24$ para a mistura dos diversos agentes cimentantes; uma seringa de insulina de $3 \mathrm{ml}$ para a inserção do material; um peso de $5 \mathrm{~kg}$ para a manutenção do conjunto matriz-cimento, papel celofane, tiras de poliéster; um paquímetro digital para a medição dos corpos-de-prova. 
Para cada material foram confeccionados 10 espécimes, divididos em quatros grupos quanto ao tipo de agente cimentante, e avaliados em dois períodos quanto à resistência máxima, 1h e 24h após a confecção do corpo-de-prova.

\subsection{1 - Espécime para o ensaio de cisalhamento}

Para a confecção dos corpos-de-prova do ensaio de cisalhamento foi utilizado uma matriz de aço em forma de disco com dimensões de $14 \mathrm{~mm}$ de diâmetro interno e 1,5mm de espessura, acoplada em um dispositivo próprio para realizar o teste denominado puncionamento (punch-test), semelhante ao elaborado por Taylor \& Margetis e modificado por Rosso e Santos (Fig. 5 e 6). Este dispositivo foi especialmente confeccionado em aço inoxidável por Mondelli, conferindo um alto grau de precisão além de um excelente ajuste de seus componentes. O dispositivo apresenta um pino posicionado em um orifício no centro da base do material responsável pelo puncionamento do material e seu deslocamento, além da área central onde a matriz é adaptada

Os materiais foram proporcionados e manipulados conforme citados anteriormente. A inserção de cada material na matriz em forma de anel foi realizada com o auxílio de uma seringa de insulina, com o propósito de diminuir a inclusão de bolhas e facilitar a inserção dos cimentos. A matriz foi posicionada sobre uma placa de vidro fina interposta com um pedaço de papel celofane. O agente cimentante foi inserido na matriz e após o completo preenchimento foi colocada um outro pedaço de papel celofane sobre o conjunto matriz-cemento e outra placa de vidro fina, 0 conjunto foi mantido com um peso de $5 \mathrm{~kg}$ durante cinco minutos para a preensão do disco de material e mais 15 minutos de espera para a presa final, para os cimentos de fosfato de zinco, fosfato com cobre e ionomérico.

Para estes três materiais foram seguidos o mesmo procedimento de preenchimento das matrizes, com uma única diferença quanto ao proporcionamento em peso, pois para cada material foram utilizadas duas dosagens de pó e oito gotas de liquido para os cimentos de fosfato de zinco convencional e com cobre, e duas dosagens de pó e quatro gotas de liquido, para o cimento de ionômero de vidro. 
Quanto ao cimento resinoso, o proporcionamento foi dividido em partes iguais das duas pastas constituindo, $0,6 \mathrm{~g}$ de ambas para o total preenchimento da matriz. Em seguida foi feita a fotopolimerização por $40 \mathrm{~s}$ em cada lado da matriz, aguardando-se $30 \mathrm{~min}$, conforme recomendação do fabricante, devido à necessidade da completa polimerização química do material.

Para todos os materiais o excesso foi removido com lâmina de bisturi $n^{\circ} 11$ para homogeneizar o conjunto matriz-cimento (Fig. 6) a fim de manter as medidas internas da matriz, pois o material ficou aderido à mesma até a realização do ensaio e com a utilização do paquímetro digital foram conferidas as dimensões dos espécimes em forma de disco ou moeda.

O conjunto matriz-cimento foi armazenado em um recipiente plástico individual para cada espécime e posteriormente colocado na estufa para ser testado em 1 h e 24 h. Para os ensaios de 1 h o espécime era armazenado a seco e, nas demais $23 \mathrm{~h}$. foram despejados $3 \mathrm{ml}$ de água deionizada no recipiente, mantido na estufa biológica a $37^{\circ} \mathrm{C}$.

Após os períodos de 1 e 24 h, os corpos-de-prova foram levados à máquina de ensaios universal EMIC (FOB-USP) com 0 dispositivo de puncionamento posicionado entre duas superfícies lisas e o conjunto matrizespécime posicionado no interior do dispositivo.

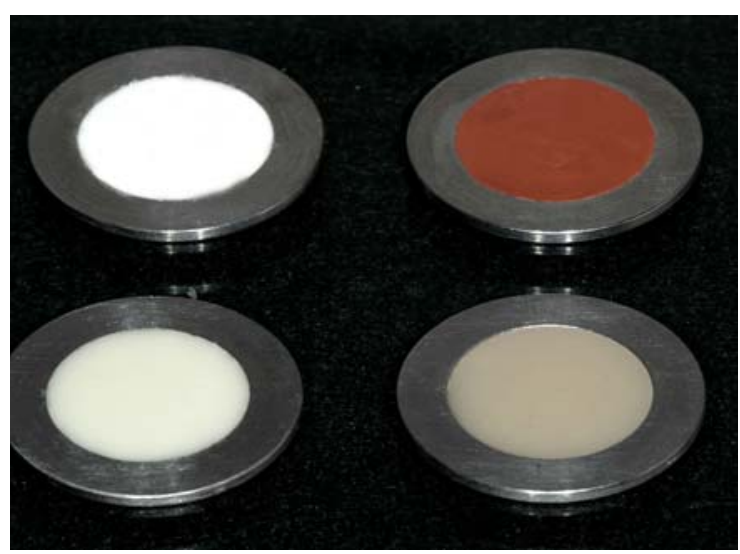

Figura 5 - Corpos-de-prova em forma de moeda no interior da matriz-anel prontos para o ensaio de cisalhamento 


\subsection{2 - Espécime para o ensaio de compressão e tração diametral}

Para os ensaios de compressão axial e diametral foi confeccionado uma matriz cilíndrica bipartida de politetrafluoretileno (PTFE) (Figs. 7 e 8), com dimensões de $4 \mathrm{~mm}$ de diâmetro e $6 \mathrm{~mm}$ de altura, com dois orifícios internos que permitiam a confecção de dois corpos-de-prova simultâneos.

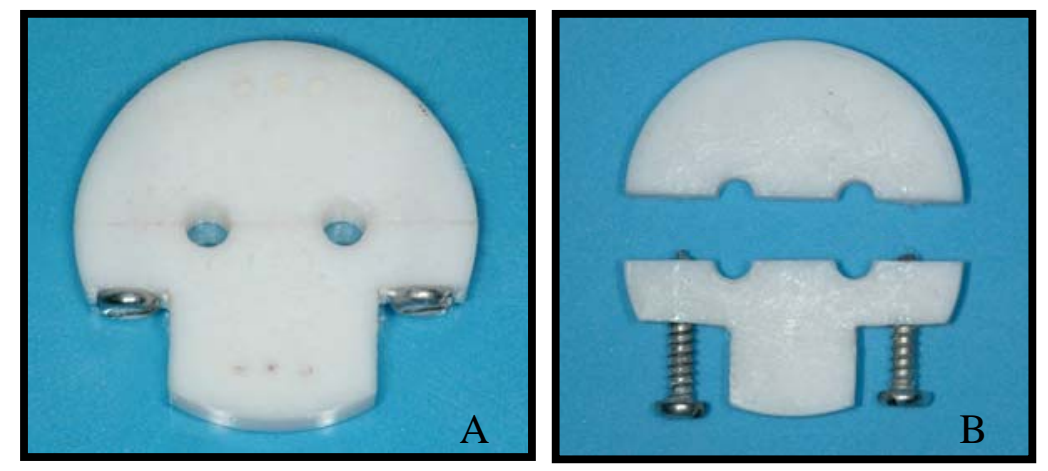

Figuras 6 e 7 - Vista frontal das matrizes bipartidas de PTFE. Em (A) matriz posicionada para a inserção do material. Em (B) Matriz posicionada após a remoção do material

Os materiais foram proporcionados, manipulados adequadamente $\mathrm{e}$ levados ao interior da matriz por meio de uma seringa de insulina de $3 \mathrm{ml}$, seguindo as mesmas recomendações do ensaio de cisalhamento (Fig. 9). Para o cimento de fosfato e fosfato com cobre foram necessárias duas medidas de pó para 8 gotas de liquido para o preenchimento dos dois orifícios. Já para o ionômero de vidro foram necessárias três medidas de pó para 6 gotas de liquido. Com relação ao cimento resinoso, a proporção das duas pastas foi de $0,7 \mathrm{~g}$ para cada uma. 


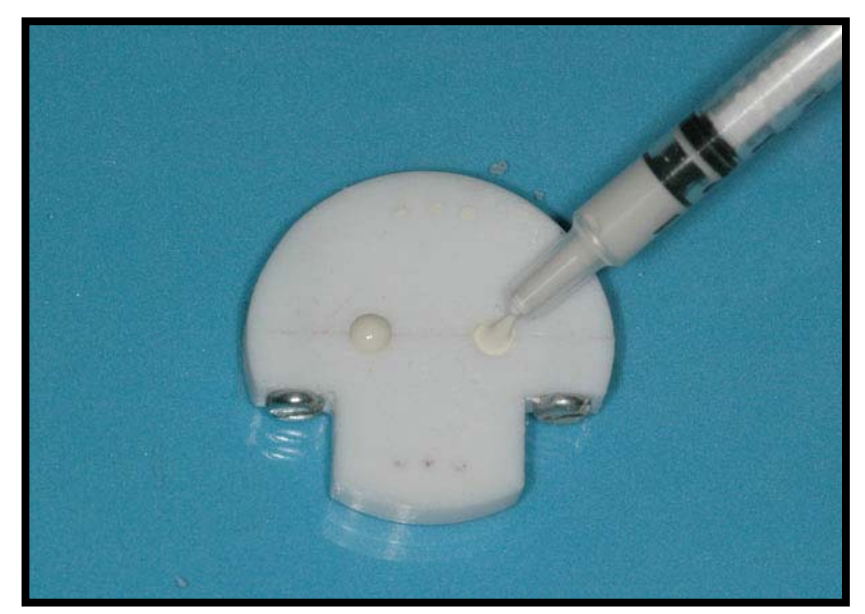

Figura 8 - Inserção do material nos orifícios da matriz montada

Os dois corpos-de-prova obtidos a partir da matriz de PTFE foram armazenados individualmente, seguindo os mesmos passos do ensaio anterior até o momento do ensaio na EMIC (Fig. 12).

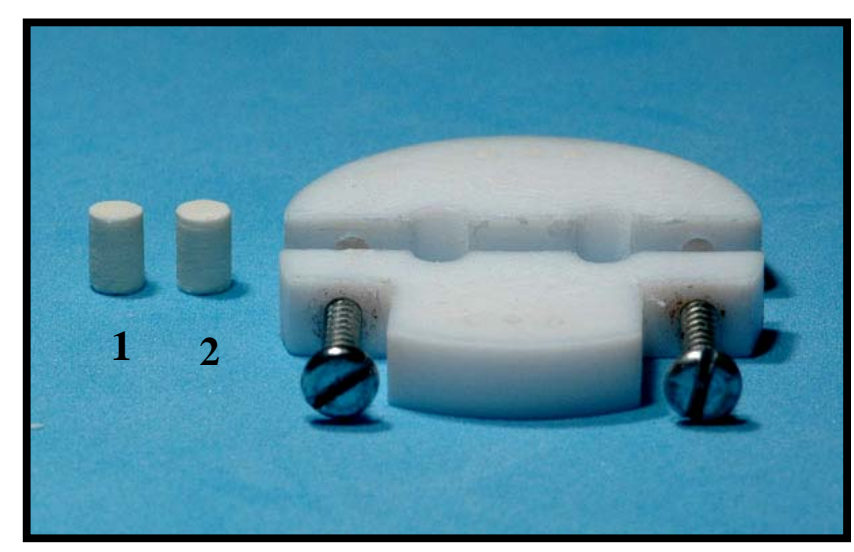

Figura 9 - Espécimes 1 e 2 depois de removidos da matriz de PTFE

\section{3 - Ensaio mecânico de cisalhamento}

Primeiramente foi retirado o conjunto matriz-cimento dos recipientes plásticos para os testes de $1 \mathrm{~h}$ e $24 \mathrm{~h}$. Somente para os testes de $24 \mathrm{~h}$ o conjunto foi secado com papel absorvente e em seguida, inserido no local apropriado do dispositivo. Apo a colocação do puncionador no centro do dispositivo, o conjunto foi posicionado entre duas superfícies lisas na máquina EMIC e pronto para ser 
ensaiado (Fig. 13). No momento do ensaio com a EMIC previamente regulada o pino central exerceu uma carga em cada material testado, deslocando o agente cimentante no centro do conjunto matriz-cimento (O material deslocado é correspondente ao diâmetro do pino). A carga necessária para a ruptura do material juntamente com a área restante do conjunto disco-agente cimentante foi medida e o cálculo para a obtenção dos valores de resistência ao cisalhamento foi determinado pela seguinte fórmula ( Fig. 14).

Resistência ao cisalhamento = Carga $/ \pi \cdot d \cdot h(\mathrm{MPa})$

Onde: $\pi=3,14$ (constante).

d = diâmetro da haste vertical do dispositivo de puncionamento.

h = Espessura da secção cortada do corpo-de-prova.
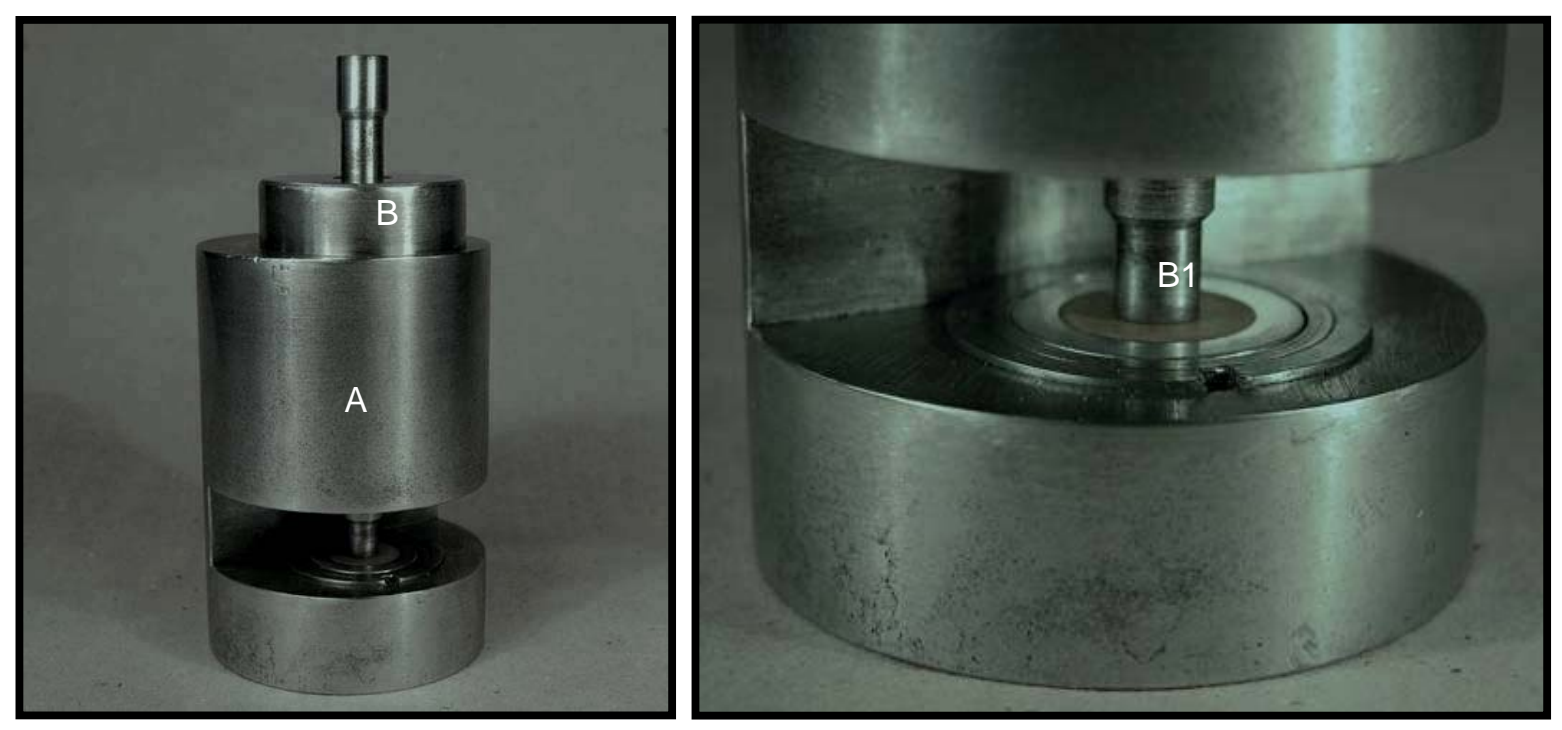

Figura 10 - Dispositivo posicionádo na EMIC pronta para o ensaio. Em (A) corpo do dispositivo. Em (B) Parte superior do puncionador. Em (B1) ponta ativa do puncionador 


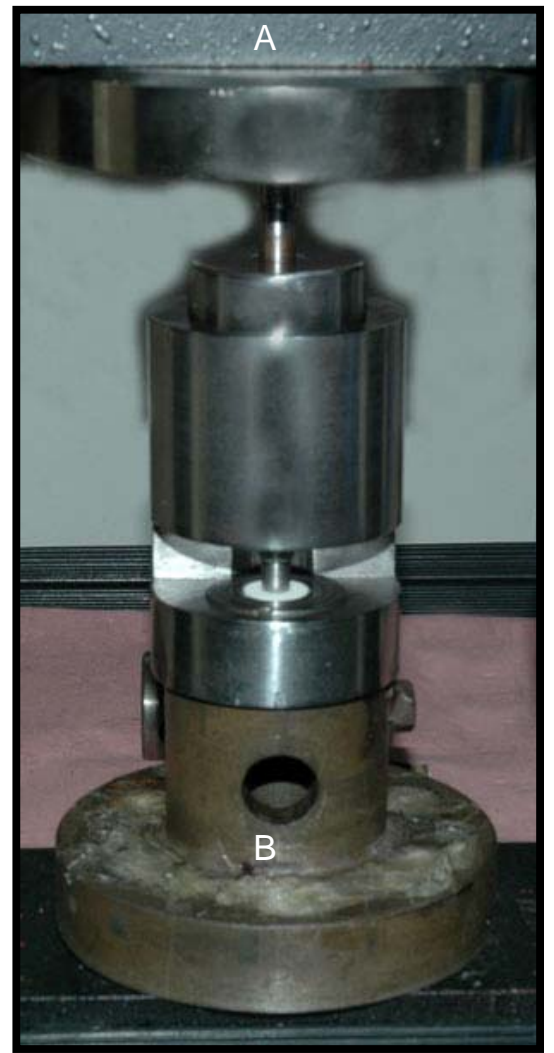

Figura 11 - Dispositivo posicionado na EMIC pronta para o ensaio. Em (A) Base superior da EMIC acoplada a célula de carga. Em (B) Base inferior da EMIC

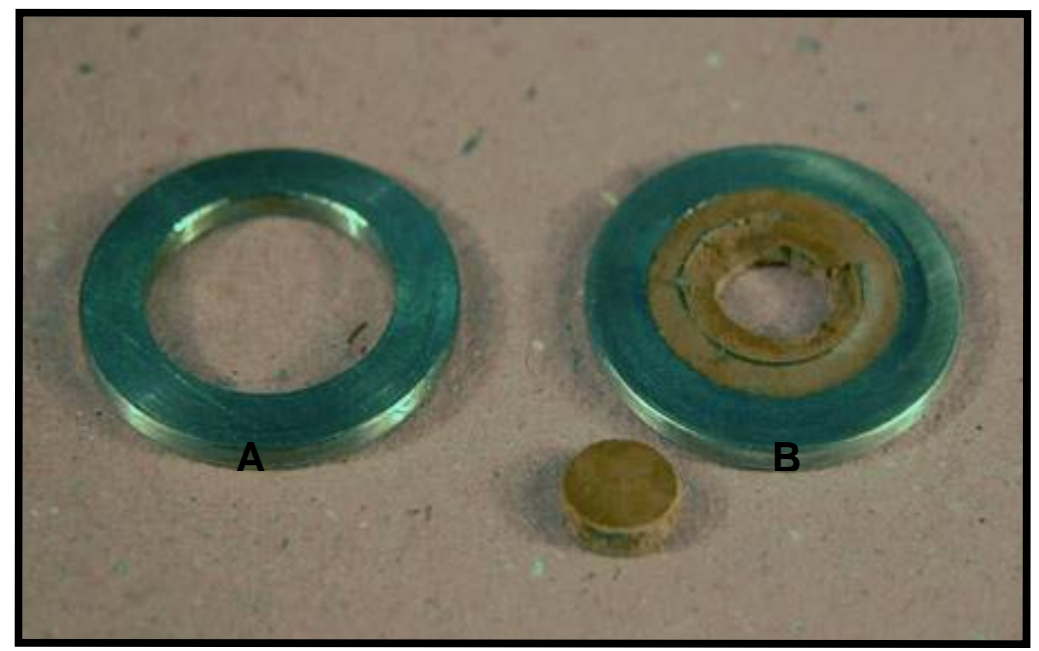

Figura 12 - Corpo-de-prova no interior da matriz antes e após ensaio. (A) Matriz pronta para a inserção do material. (B) Corpo-de-prova após puncionamento 


\section{4 - Ensaios mecânicos de compressão axial e diametral}

Os procedimentos para os espécimes a serem testados após $1 \mathrm{~h}$ e $24 \mathrm{~h}$ de confecção foram semelhantes ao ensaio de cisalhamento. Com os corpos-deprova prontos para serem testados, a única diferença entre os ensaios de compressão axial e diametral foram quanto ao posicionamento dos espécimes em relação às bases de sustentação da máquina de ensaios universal, pois para o teste de resistência à compressão a disposição do espécime foi no sentido vertical e para o teste de resistência de tração diametral a disposição do espécime foi no sentido horizontal.

Apenas a base superior em que estava acoplada a célula de carga sofreu movimentação, o que determinou a carga de compressão axial, registrada pela máquina de ensaio universal, (Fig. 15 e 16) após a primeira ruptura do corpo-deprova. No ensaio de tração diametral o seccionamento do corpo-de-prova em duas partes caracterizou a ruptura do material e o padrão de fratura do espécime (Fig. 17 e 18).

Após a obtenção das cargas necessárias para a ruptura dos corpos-deprova, as resistências à compressão axial e diametral, foram calculadas.

Resistência à compressão = cargal $\pi \cdot r^{2} \quad(\mathrm{MPa})$

Onde: $\pi=3,14$ (constante)

$r=$ raio da base do cilindro

Resistência à tração diametral = 2.Carga/ $\pi \cdot$ d.h (MPa)

Onde: $\pi=3,14$ (constante)

d = diâmetro do corpo-de-prova

h = atura do corpo-de-prova 

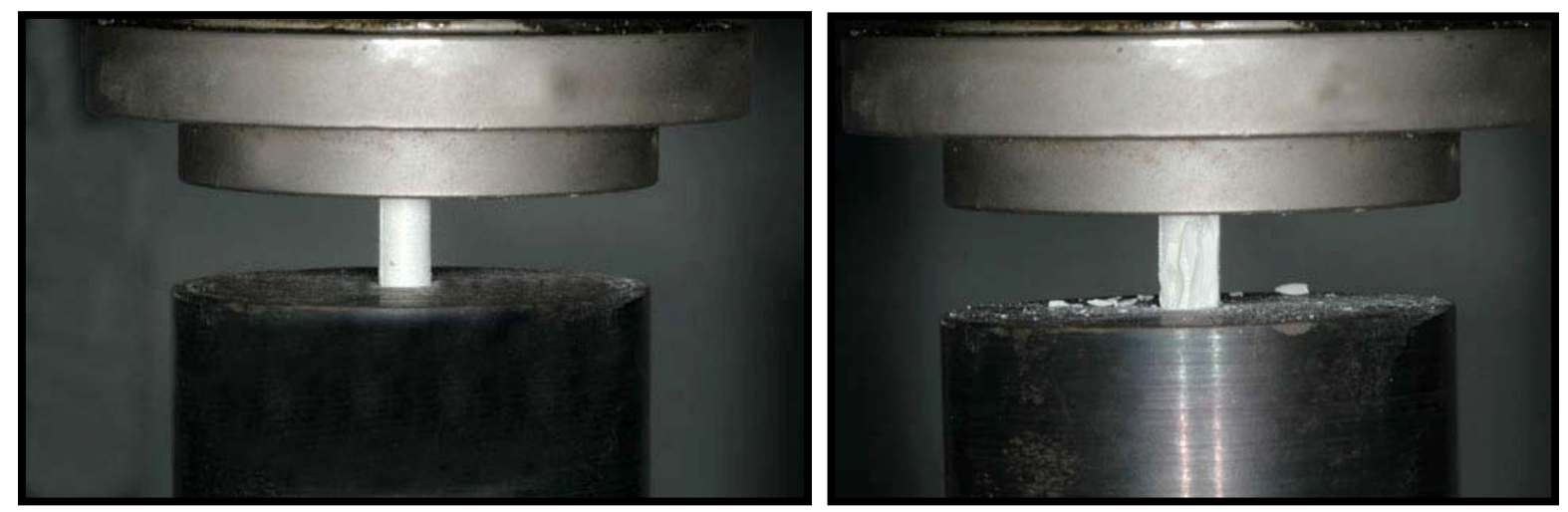

Figuras 13 e 14 - Momento do ensaio de compressão axial antes e após a ruptura
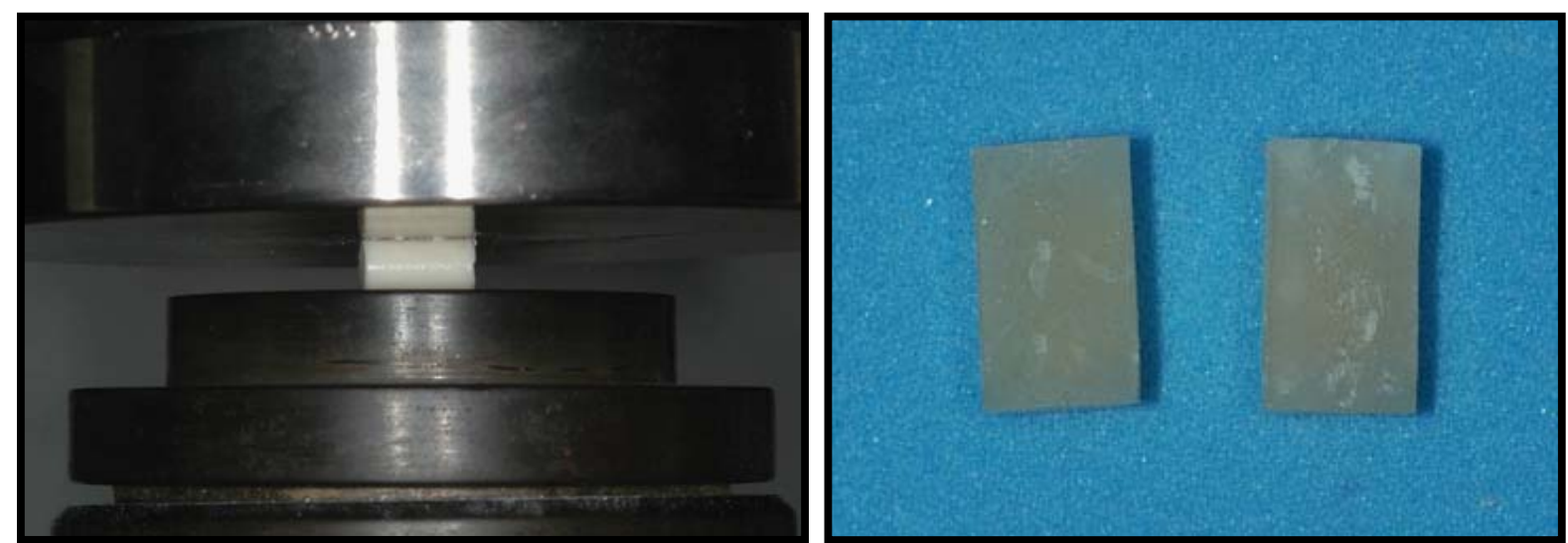

Figuras 15 e 16 - Momento do ensaio de tração diametral e padrão de ruptura dos espécimes

Para todos os testes mecânicos a máquina de ensaios utilizada foi a EMIC do Centro Integrado de Pesquisas da Faculdade de Odontologia de Bauru (CIP/FOB-USP), com uma célula de carga de $500 \mathrm{kgf}$, em velocidade regulada para $0,5 \mathrm{~mm} / \mathrm{min}$, com o software denominado Tesc e seus respectivos scripts de ensaio para compressão axial e diametral e cisalhamento

No desenvolvimento da presente pesquisa foram seguidas as Especificações pertinentes, formuladas pela "International Organization for Standardization" n9917-1(E) (ISO) e "American Dental Association" n96 (ADA) para os ensaios de compressão, o único que apresenta norma específica para os agentes cimentantes.

A resistência foi medida em MPa conforme a recomendação das Normas. Com relação aos ensaios de tração diametral e o de cisalhamento foram seguidas 
as mesmas recomendações, apesar de não haver nenhuma entidade com uma norma específica para tais testes.

Durante a parte prática do presente trabalho, todas as operações foram efetuadas em ambiente com controle da umidade relativa e da temperatura, como exigido em pesquisas de caráter científico. 
RESULTADOS 



\section{RESULTADOS}

Os resultados obtidos foram registrados em tabelas e gráficos e tratados estatisticamente, por meio de Análise de Variância a dois critérios (ANOVA), seguidos de teste para comparações individuais (Tukey), com nível de probabilidade de 5\%, para cada ensaio mecânico,com os quatro agentes cimentantes e nos dois períodos analisados.

Seguem os resultados das médias para os diferentes ensaios mecânicos, com as tabelas e gráficos analisados separadamente, visto que a comparação de material entre testes mecânicos não se faz necessária, devido apresentarem espécimes diferentes para cada ensaio.

\subsection{Resistência ao cisalhamento}

Na tabela 2 são apresentados as médias entre os materiais e os dois períodos, para a resistência ao cisalhamento. O que se observa é o cimento resinoso dual, com os maiores valores de resistência ao cisalhamento, tanto em 1 hora quanto em 24 horas, seguido pelo fosfato de zinco com cobre que, após 1 hora apresentou valores semelhantes ao fosfato de zinco convencional, mas após 24 horas obteve uma resistência superior. Já o ionômero de vidro apresentou os valores mais baixos de resistência ao cisalhamento.

A partir da análise de variância e após a comparação individual entre grupos (Tukey) com $p<0,05$, foi observado que para o fosfato de zinco e o ionômero de vidro não houve diferença estatística para os dois períodos analisados quanto a essa resistência. Para o cimento resinoso e o fosfato de zinco com cobre foram encontrados diferenças estatisticamente significantes entre os dois períodos avaliados.

No gráfico 1 observou-se a diferença entre os agentes cimentantes quanto a resistência medida em $\mathrm{MPa}$, com destaque para o cimento resinoso e o fosfato de zinco com cobre, obtendo os valores mais altos e diferença estatisticamente significante entre os períodos de 1 hora e 24 horas. 
Tabela 2 - Médias obtidas com espécimes dos quatro agentes cimentantes para o ensaio de cisalhamento em MPa nos períodos de 1 e 24 horas

\begin{tabular}{l|c|c|c|c}
\multicolumn{1}{c|}{ Espécime } & $\begin{array}{c}\text { Fosfato de } \\
\text { zinco }\end{array}$ & $\begin{array}{c}\text { Fosfato de zinco } \\
\text { com cobre }\end{array}$ & $\begin{array}{c}\text { Ionômero de } \\
\text { vidro }\end{array}$ & $\begin{array}{c}\text { Resina } \\
\text { composta }\end{array}$ \\
\hline Média (1 hora) & $32,00( \pm 6,38)$ & $31,68( \pm 7,53)$ & $9,76( \pm 1,66)$ & $145,18( \pm 7,97)$ \\
\hline Média (24Horas) & $27,46( \pm 9,27)$ & $52,56( \pm 3,57)$ & $10,46( \pm 0,86)$ & $181,55( \pm 20,04)$
\end{tabular}

Gráfico 1 - Resistência ao cisalhamento (valores em MPa) dos agentes cimentantes em dois períodos diferentes.

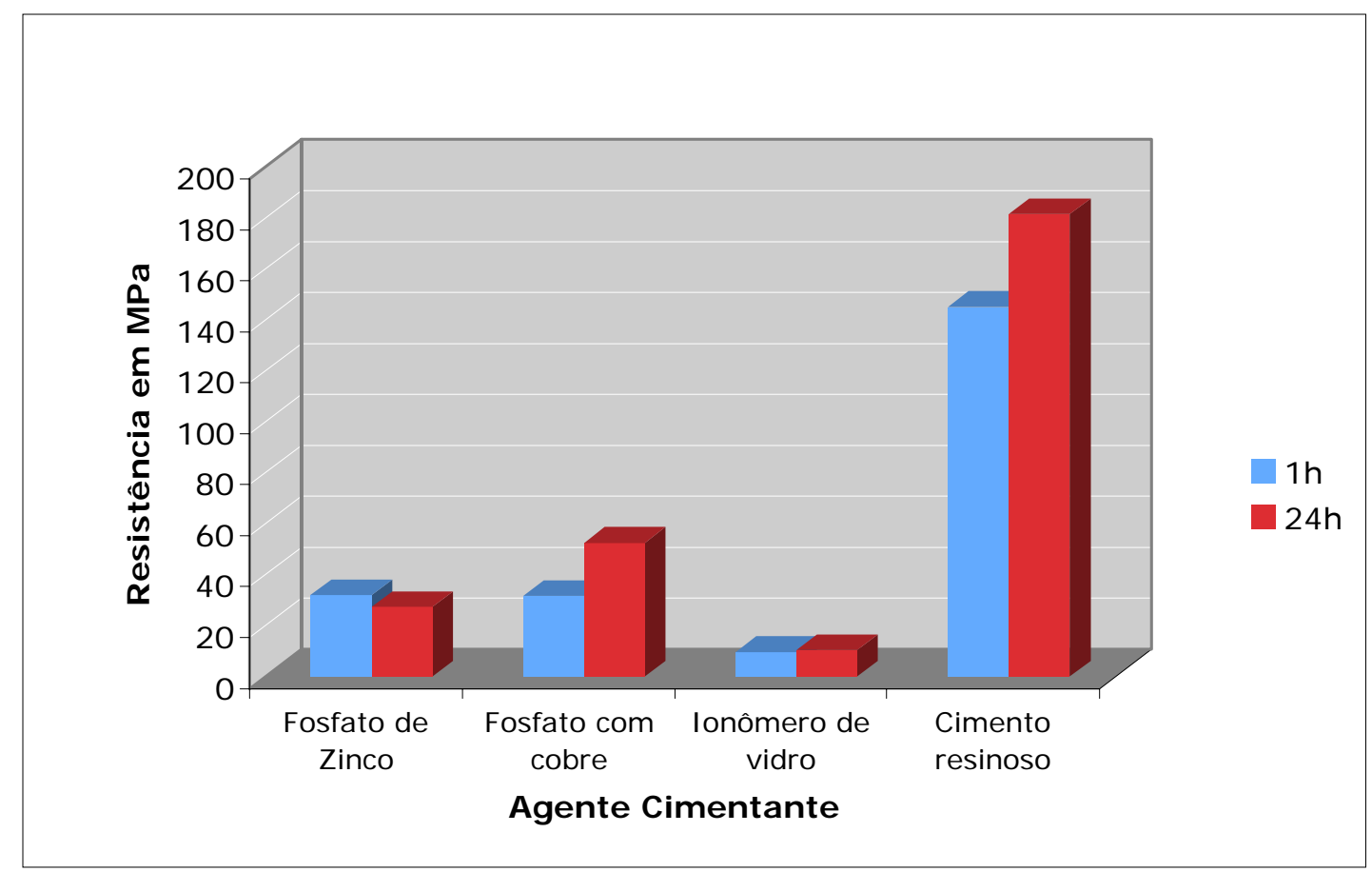

\subsection{Resistência à Compressão}

Para os ensaios de compressão axial, as médias destacadas na tabela 3 demonstram novamente que o cimento resinoso dual obteve os maiores valores de resistência, com um aumento significativo de 1 hora para 24 horas, seguido do fosfato de zinco convencional, fosfato de zinco com cobre e por último o ionômero de vidro. Foi observado que, mesmo o cimento de ionômero de vidro apresentando os valores mais baixos de resistência, houve um aumento maior que o dobro com relação aos dois períodos analisados. A análise estatística comparativa destacou 
que não houve diferença estatisticamente significante entre os dois períodos analisados, tanto para o fosfato de zinco quanto para o fosfato de zinco com cobre, e quando comparados estes materiais entre si.

O cimento resinoso apresentou diferenças estatisticamente significantes nos dois períodos analisados, juntamente com o cimento de ionômero de vidro, e em relação aos demais agentes cimentantes analisados.

Foi observado, no gráfico 2, a grande diferença da resistência à compressão para o cimento resinoso com os demais agentes cimentantes e apenas o cimento de ionômero de vidro na 1 hora apresentou valores abaixo da média, mantendo-se a média entre os cimentos de fosfato de zinco e o fosfato de zinco com cobre.

Tabela 3 - Médias obtidas dos espécimes dos quatro agentes cimentantes para o ensaio de compressão axial em MPa, nos períodos de 1 e 24 horas

\begin{tabular}{c|c|c|c|c} 
Espécime & Fosfato de zinco & $\begin{array}{c}\text { Fosfato de zinco } \\
\text { com cobre }\end{array}$ & $\begin{array}{c}\text { Ionômero de } \\
\text { vidro }\end{array}$ & $\begin{array}{c}\text { Resina } \\
\text { composta }\end{array}$ \\
\hline Média (1 h) & $53,60( \pm 6,59)$ & $52,94( \pm 9,44)$ & $21,02( \pm 3,33)$ & $254,85( \pm 20,59)$ \\
\hline Média (24 h) & $65,94( \pm 6,08)$ & $49,53( \pm 5,48)$ & $50,02( \pm 3,40)$ & $301,50( \pm 22,90)$
\end{tabular}

Gráfico 2 - Resistência à compressão (valores em MPa) dos agentes cimentantes em diferentes períodos

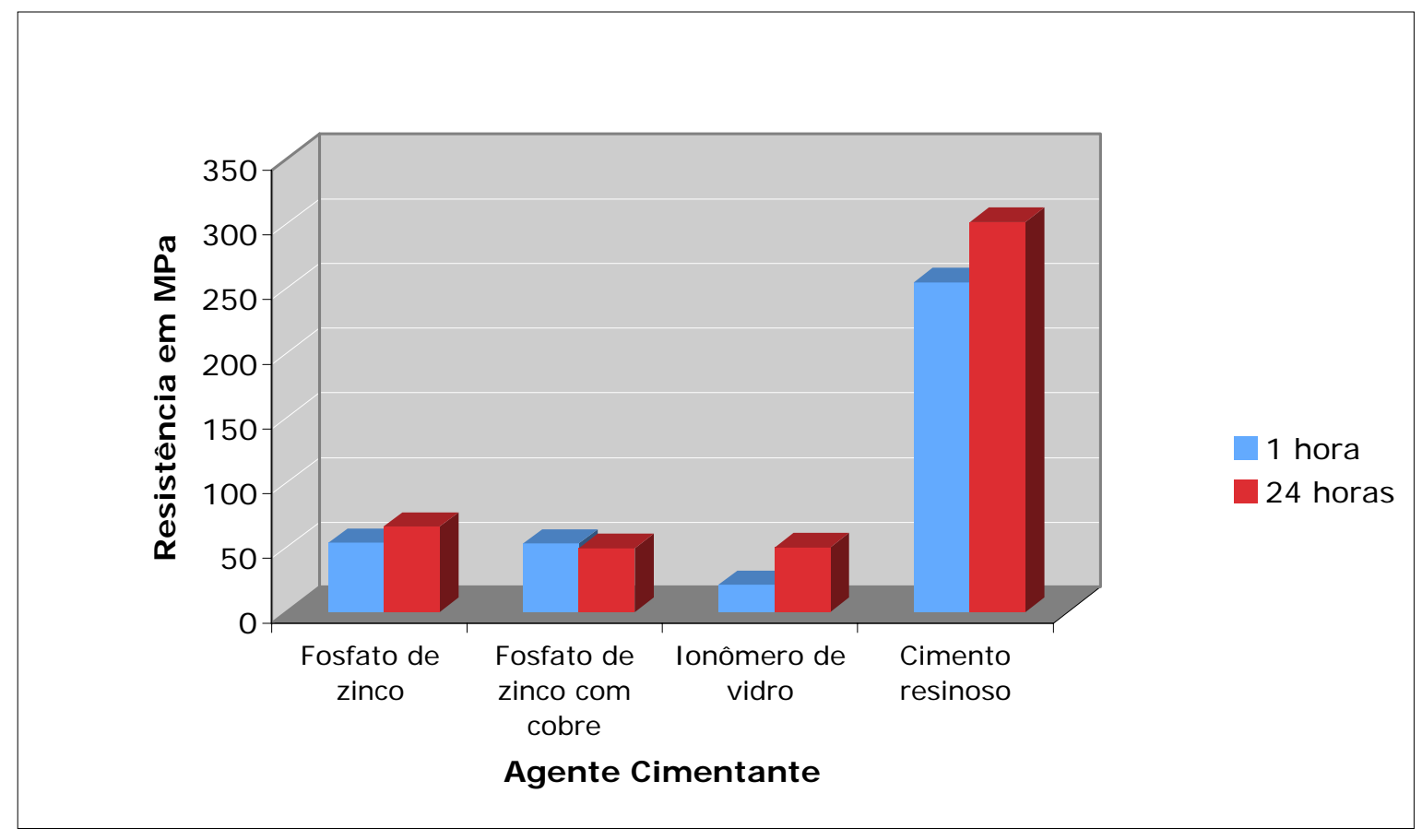




\subsection{Resistência à Tração Diametral}

Finalmente, para os ensaios de tração diametral, as médias observadas para os agentes cimentantes na tabela 4 demonstraram que o cimento resinoso obteve os maiores valores entre os diferentes materiais. Quanto aos diferentes períodos, apenas o fosfato de zinco e o cimento resinoso apresentam valores de resistência estatisticamente significantes. Para o fosfato de zinco com cobre e cimento de ionômero de vidro além de apresentarem os valores mais baixos tanto entre os materiais quanto nos períodos, não apresentaram estatisticamente significância quando comparados individualmente.

Novamente, somente o cimento resinoso apresentou resistência estatisticamente significantes quando comparado entre os períodos e os agentes cimentantes avaliados.

No gráfico 3 foram observados os menores valores de resistência com relação aos demais ensaios mecânicos pelas médias obtidas para todos os materiais e novamente o cimento resinoso destacou-se por apresentar os maiores valores com relação aos demais materiais e com a maior variação entre os dois períodos analisados.

Tabela 4 - Médias obtidas dos espécimes dos quatro agentes cimentantes para o ensaio de tração diametral em MPa, nos períodos de 1 e 24 horas

\begin{tabular}{l|c|c|c|c} 
Espécime & $\begin{array}{c}\text { Fosfato de } \\
\text { zinco }\end{array}$ & $\begin{array}{c}\text { Fosfato de } \\
\text { zinco com cobre }\end{array}$ & $\begin{array}{c}\text { Ionômero de } \\
\text { vidro }\end{array}$ & Resina composta \\
\hline Média (1 h) & $4,26( \pm 0,68)$ & $3,68( \pm 1,05)$ & $3,01( \pm 0,26)$ & $36,69( \pm 3,40)$ \\
\hline Média (24 h) & $7,23( \pm 1,45)$ & $4,10( \pm 0,66)$ & $4,41( \pm 0,75)$ & $50,56( \pm 2,74)$
\end{tabular}


Gráfico 3 - Resistência à Tração Diametral (valores em MPa) dos agentes cimentantes em diferentes períodos

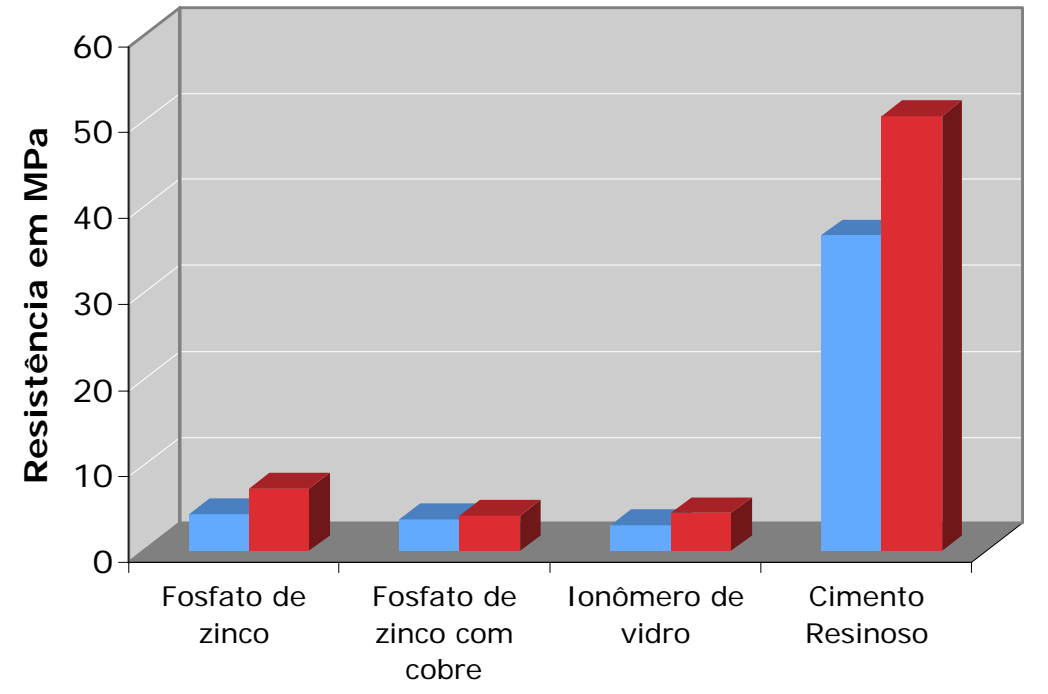

Agente Cimentante 
DISCUSSÃO 



\section{DISCUSSÃO}

\section{1 - MÉTODOS}

Cada estudo, principalmente por ser laboratorial, sempre, adota padrões específicos de forma criteriosa, desde a escolha do material, passando pelo proporcionamento e manipulação, confecção dos espécimes em ambiente controlado até o momento de ser realizado o ensaio mecânico (KUMBULOGLU, LASSILA, USER, VALLITTU ${ }^{19}$, 2004, LI; WHITE ${ }^{22}$, 1999, WHITE; YU $\left.{ }^{44}, 1993\right)$.

A escolha do material é determinada de acordo com o parecer de autores com relação à qual marca comercial utilizar, que é o diferencial entre os estudos referentes aos ensaios que avaliam as propriedades mecânicas. Para estes ensaios, relatados na literatura, o que se observa de forma importante é o padrão de resistência à compressão exigido pelas Normas da "ADA n `96" e "ISO 9917:1(E)", para os agentes cimentantes e os valores obtidos frente as diferentes pesquisas realizadas. Visto que não há uma especificação da marca comercial que foi utilizada pelas importantes entidades, não se deve afirmar que diferentes marcas, mesmo sendo de um mesmo tipo de agente cimentante, necessariamente, tenham que apresentar valores de compressão similares (GERDULLO; NAKAMURA; SUGA; NAVARRO ${ }^{16}$, 1995, LEVARTOSVKY, KUIYNU; GEORGESCU; GOLDSTEIN ${ }^{20}$, 1994, MONDELLI; MARTINS; STEAGALL; NAVARRO ${ }^{25}$, 1994, PALMA et al ${ }^{30} .1994$, POWERS; FARAH; CRAIG ${ }^{33}$, 1976, PRENTICE; TYAS; BURROW ${ }^{35}$, 2005).

Nesta pesquisa foi avaliado somente materiais nacionais, devido à maior facilidade de acesso aos fabricantes, além de custo mais reduzido, frente aos cimentos importados. A única exceção foi o cimento de fosfato de zinco com cobre, que foi incluído na pesquisa, devido ser um material americano desconhecido quanto as suas propriedades e pelos clínicos e pesquisadores brasileiros.

Cada cimento foi pesado de acordo com a sua forma de apresentação, pó e líquido para os cimentos de fosfato de zinco, de fosfato de zinco com cobre e de ionômero de vidro e pasta/pasta para o cimento resinoso dual, manipulados segundo recomendação do fabricante, com o propósito de diminuir o número de variáveis que pudessem interferir na composição do espécime. 
O fosfato de zinco com cobre seguiu exatamente as recomendações do fabricante, mas apenas o pó foi utilizado com o liquido do fosfato convencional, como recomendação própria do fabricante (COOLEY \& COOLEY).

A escolha do cimento de fosfato com cobre para esta pesquisa visou analisar quais vantagens a presença do cobre teria sobre as propriedades mecânicas, visto que não sendo um material muito conhecido e assim pouco utilizado, quais as características, além das propriedades anticariogênicas poderia apresentar (FOLEY; EVANS; LLOYD; BLACKWELL ${ }^{14}, 2001$, FRASER $^{15}$, 2004).

Quanto ao cimento de ionômero de vidro foi utilizado um verniz protetor, para proteger o cimento contra a umidade presente no ar, principalmente nos seus primeiros minutos de presa, a fim de evitar que o material sofresse trincas ou rachaduras, ou mesmo sinérese, influenciando no resultado final de resistência.

Para o cimento resinoso dual a pesagem do material foi feita em partes iguais, desde que a quantidade específica para o total preenchimento das matrizes foi determinada a partir das suas dimensões, o que implicou em dividir sempre em duas partes iguais a pasta base e a catalisadora. Após a mistura foi utilizado um fotopolimerizador aplicado sobre os espécimes durante $40 \mathrm{~s}$ em cada lado da matriz e esperado 30 minutos para a remoção dos corpos-de-prova, a fim de aguardar uma completa polimerização do material, seguindo recomendações do fabricante.

Para a confecção dos espécimes do ensaio de cisalhamento foram seguidas recomendações referentes a trabalhos anteriores para a obtenção do corpo-de-prova, pois este ensaio não apresenta nenhuma norma específica frente as entidades como "ADA e ISO", além de ser um ensaio de cisalhamento por puncionamento que se diferencia dos testes de cisalhamento tradicionais (CIARELLI; ELIAS; NAVARRO; CARVALHO ${ }^{9}$, 2001, MONDELLI; MARTINS; STEAGALL; NAVARRO ${ }^{25}$, 1994, ROYDHOUSE; LEWIS ${ }^{38}, 1969$, SMITH; COOPER $\left.^{42}, 1974\right)$.

Por esse motivo a literatura não é vasta quanto a aplicação deste teste de cisalhamento por puncionamento envolvendo agentes cimentantes, mesmo sendo de fácil execução e apresentando resultados satisfatórios (CIARELLI; ELIAS; NAVARRO; CARVALHO ${ }^{9}$, 2001). ROYDHOUSE; LEWIS ${ }^{38}$, em 1969 afirmavam que o teste de cisalhamento por puncionamento tem sua aplicação limitada, exceto quando os materiais analisados apresentam características semelhantes ou quando o diâmetro do pino puncionador é similar a todos os espécimes. 
O que é importante afirmar é que devido às modificações existentes ao longo dos anos desse dispositivo, apenas os trabalhos de (CIARELLI; ELIAS; NAVARRO; CARVALHO ${ }^{9}, 2001$, MONDELLI; MARTINS; STEAGALL; NAVARRO ${ }^{25}$, 1994) podem ser comparados com esta pesquisa.

Dessa forma o ensaio realizado se assemelha aos estudos de (CIARELLI; ELIAS; NAVARRO; CARVALHO ${ }^{9}$, 2001, MONDELLI; MARTINS; STEAGALL; NAVARRO $^{25}$, 1994), com uma diferença apenas na confecção dos espécimes, pois o cuidado em obter o menor número de bolhas no interior do corpo-de-prova proporcionou a todos os cimentos a inserção do material com o uso de seringas de 3 ml. A espera para a remoção do corpo-de-prova também foi realizada em ambiente natural, aguardando-se 15 minutos para a completa polimerização, visto que o conjunto não teria como ser levado ao interior de uma estufa, pois um peso de $5 \mathrm{~kg}$, foi posicionado no centro do conjunto matriz, papel celofane e placa de vidro, impedindo dessa forma a movimentação do conjunto matriz-espécime e qualquer alteração visual no corpo-de-prova. Após os 15 minutos, o conjunto foi levado a um recipiente de plástico e testado após 1 hora e 24 horas.

O período de 1 h serviu para analisar o quanto o corpo-de-prova já adquiriu de resistência, visto que, analisando um parâmetro clínico, um procedimento de cimentação de uma peça protética após esse período já deve apresentar uma resistência satisfatória ao deslocamento e remoção. O período de 24 horas segundo as normas para os ensaios de compressão e alguns autores seria o tempo necessário para o material adquirir sua resistência máxima quanto aos agentes cimentantes.

Outro fator a ser discutido é quanto ao tipo de máquina de ensaios universal aliada a velocidade regulada para os testes de resistência, pois nesse trabalho foi utilizada a EMIC, e em vários outros artigos são utilizadas outras máquinas universais reguladas com velocidades diferentes, o que pode influir na concordância dos valores obtidos entre os diferentes trabalhos quanto às propriedades mecânicas. (CIARELLI; ELIAS; NAVARRO; CARVALHO ${ }^{9}, 2001$, MONDELLI; MARTINS; STEAGALL; NAVARRO ${ }^{25}$, 1994, ROYDHOUSE; LEWIS ${ }^{38}$, 1969, SMITH; COOPER $\left.{ }^{42}, 1974\right)$.

Para os ensaios de compressão e tração diametral os espécimes tinham os mesmos padrões de dimensão e proporção de tamanho quanto à altura e diâmetro, seguindo a referencia das normas da "ADA n96" e "ISO 9917-1(E)" para 
resistência à compressão, o que não corrobora com alguns autores que confeccionaram corpos-de-prova de tamanhos e proporções diferentes para ambos os ensaios

É importante ressaltar que, quando forem utilizados corpos-de-prova com diferentes tamanhos, mas com a proporção altura/diâmetro igual, os resultados obtidos podem ser comparados quanto aos valores de resistência, o que não ocorre quando a proporção entre altura e diâmetro não corresponde entre os diferentes trabalhos.

Certamente após a década de 90, a ADA n96 estabeleceu suas especificações de acordo com as normas da ISO 9917:1(E), com o intuito de facilitar a comparação entre os resultados e a padronização dos corpos-de-prova, pois antes disso a "ADA" apresentava dimensões dos espécimes de $12 \mathrm{~mm}$ de altura por $6 \mathrm{~mm}$ de diâmetro, contra $6 \mathrm{~mm}$ de altura por $4 \mathrm{~mm}$ de diâmetro para os espécimes da "ISO". O que não se consegue esclarecer é o porquê da alteração da "ISO" com relação à proporção dos espécimes, visto que sempre foi um padrão para os ensaios mecânicos realizados na engenharia, um corpo cilíndrico apresentar uma proporção de 2:1 com relação a altura e diâmetro (FLEMING; MARQUIS; SHORTALL ${ }^{11}, 1999$, MCCOMB; SIRIKO; BROWN ${ }^{24}$, 1984, PRENTICE; TYAS; BURROW ${ }^{35}, 2005$, VIEIRA $\left.{ }^{43}, 1965\right)$.

A justificativa provável para o caso dos agentes cimentantes em relação aos corpos-de-prova da "ADA" seria em relação, talvez, ao tamanho, pois uma grande quantidade de material poderia ocasionar alterações dimensionais maiores em um espécime grande, mas o porquê de alterar a proporção de 1,5:1 estabelecida pela "ISO" não é esclarecida na literatura, visto que a dimensão do corpo-de-prova poderia ser diminuído, mas mantendo a proporção ideal.

As normas utilizadas nesse trabalho respeitam as entidades internacionais, visto que a título de comparação, mesmo não concordando com a proporção dos espécimes, não se poderia obter resultados comparáveis com os demais artigos citados na literatura, conforme explicado anteriormente (FLEMING; MARQUIS; SHORTALL ${ }^{13}$, 1999, MCCOMB; SIRIKO; BROWN ${ }^{24}, 1984$, PRENTICE; TYAS; BURROW $\left.{ }^{35}, 2005\right)$.

Outro aspecto que merece ser comentado diz respeito a confecção das matrizes para a realização do ensaio, pois as normas recomendam matrizes de aço ou qualquer outro material que não tenha aderência aos agentes cimentantes. 
Dessa forma, o politetrafluoretileno (PTFE) foi escolhido para a obtenção dos espécimes, visto que não possibilitou aderência nenhuma aos quatro agentes cimentantes testados.

Outro detalhe foi em relação à matriz confeccionada com dois orifícios, com o intuito de dinamizar a confecção dos corpos-de-prova sem perder a qualidade do material e do espécime obtido, pois, a partir de diversos ensaios comparados entre espécimes obtidos de forma única e com dois espécimes, não foram encontradas alterações significantes nos valores obtidos entre os espécimes e nenhuma alteração quanto ao espécime e o material analisado.

Da mesma forma como no cisalhamento foram utilizadas seringas de $3 \mathrm{ml}$ para a obtenção de dois corpos-de-prova simultâneos e removidos após 15 minutos, nas mesmas condições já discutidas anteriormente.

Todos os espécimes foram armazenados em recipientes plásticos, em estufa biológica a $37^{\circ} \mathrm{C}$ e umidade relativa a $50 \%$ concordando com os demais autores que realizaram pesquisas semelhantes.

Quanto à realização dos ensaios mecânicos utilizou-se a EMIC para os testes de resistência ao cisalhamento, compressão e tração diametral com uma célula de carga de $500 \mathrm{kgf}$ e velocidade regulada de de 0,5 mm/min, mesmo sendo uma máquina de ensaios universal, não deve ser comparada a outras diferentes máquinas presentes nos diversos laboratórios de pesquisa, mas certamente a finalidade de obter os valores de carga de ruptura são os mesmos e possivelmente os valores encontrados são semelhantes.

Abordado os tópicos deste método, pode-se afirmar que, através dos resultados obtidos frente aos diferentes testes mecânicos, os trabalhos que seguirem a metodologia com esta pesquisa podem ser comparados em todos os aspectos analisados e discutidos; já os trabalhos que não seguirem essa padronização, podem ser comparados, não se afirmando porém que os valores obtidos, mesmo que sejam semelhantes a esta pesquisa sejam fiéis (FLEMING; MARQUIS; SHORTALL ${ }^{11}, 1999$, MCCOMB; SIRIKO; BROWN ${ }^{24}, 1984$, , MONDELLI; MARTINS; STEAGALL; NAVARRO ${ }^{25}$, 1994, PALMA; NAVARRO; ISHIKIRIAMA; MARANGONI ${ }^{30}, 1994$, PRENTICE; TYAS; BURROW ${ }^{35}, 2005$ WHITE; YU $\left.{ }^{44}, 1993\right)$. 


\section{2 - RESULTADOS}

Os trabalhos experimentais realizados em laboratório tentam reproduzir ou pelo menos simular as condições do ambiente bucal.

As cargas oclusais atuam de forma direta nos dentes e nas restaurações e indiretamente nos materiais cimentantes. Os agentes cimentantes de uma restauração sofrem esses esforços e são materiais responsáveis por manter a integridade da interface entre dente/restauração, apresentando um importante papel no procedimento restaurador. (ANUSAVICE ${ }^{2}$, 2005, ROSENSTIEL; LAND; CRISPIN $\left.^{36}, 1998\right)$.

Dessa forma, uma análise criteriosa a respeito de cada material testado, quanto as propriedades mecânicas foi considerado, para estabelecer, qual agente cimentante apresentaria os maiores valores médios com relação ao cisalhamento, compressão axial e diametral nos diferentes períodos analisados.

Os resultados obtidos para o cisalhamento mostraram que o cimento resinoso apresentou os valores mais altos de resistência nos dois períodos, com um aumento significante entre os mesmos, o que implica atribuir ao material segundo alguns autores, que a resistência final é obtida após 24 horas, apesar de que para este cimento não se ter encontrado relatos na literatura com respeito a esse ensaio.

Já o cimento de ionômero de vidro apresentou os menores valores médios em ambos os períodos; dos resultados obtidos para a marca comercial aqui analisada houve valores próximos quando comparada com resultados de diferentes marcas comerciais deste material. O que não foi aqui observado foi o aumento da resistência com relação aos dois diferentes períodos, discordando de alguns relatos na literatura que mostram aumento da resistência do ionômero de vidro de 1 para 24 horas (CIARELLI; ELIAS; NAVARRO, CARVALHO ${ }^{9}, 2001$ ).

Com relação aos cimentos de fosfato de zinco e fosfato de zinco com cobre, os resultados também foram abaixo do cimento resinoso, mas bem maiores que do cimento de ionômero de vidro, discordando dos resultados do trabalho de MONDELLI; MARTINS; STEAGALL; NAVARRO ${ }^{25}$ em 1994.

O que é interessante destacar é que o cimento de fosfato de zinco com cobre, obteve melhores resultados após 24 horas no ensaio de cisalhamento , demonstrando um aumento significativo nos dois períodos, podendo fazer uma abordagem de que a presença do cobre poderia influenciar o aumento da 
resistência, pois o único elemento que se diferencia na composição de ambos os materiais seria este elemento.

Entre os cimentos analisados quanto à resistência ao cisalhamento, apenas o fosfato de zinco e o cimento de ionômero de vidro puderam ser comparados com outros trabalhos, pois a literatura pertinente não apresenta nenhuma pesquisa avaliando o fosfato de zinco com cobre e o cimento resinoso pelo teste de cisalhamento por puncionamento.

Quanto aos resultados dos ensaios de compressão a literatura pertinente apresenta vários trabalhos que podem ser comparados com os valores obtidos nessa pesquisa (KUMBULOGLU; LASSILA; USER; VALLITTU ${ }^{19}$, 1999, NICHOLSON; MCKENZIE ${ }^{22}$, 1999, LI; WHITE ${ }^{28}$, 2004).

O que se observa quanto a este teste é que as médias são mais altas em relação ao teste de cisalhamento por puncionamento e de tração diametral. A importância dos cimentos apresentarem uma resistência à compressão maior é bem satisfatória, pois grande parte das tensões que atuam no ambiente bucal são de origem compressivas, o que destaca a importância do material por apresentar resultados satisfatórios (ANUSAVICE $\left.{ }^{2}, 2005\right)$.

Novamente o cimento resinoso apresentou os valores mais altos enquanto o ionômero de vidro com os valores mais baixos, mas é válido ressaltar que segundo alguns autores, com o passar das horas, a resistência do material duplicou, que aliás não foi aqui comprovado (PALMA; NAVARRO; ISHIKIRIAMA; MARANGONI ${ }^{30}$, 1994, PRENTICE; TYAS; BURROW ${ }^{35}$, 2005,).

Já o fosfato de zinco e o fosfato de zinco com cobre demonstraram que, com 1 hora, praticamente já atingiram sua resistência máxima, mesmo apresentando uma pequena variação de diminuição da resistência com $24 \mathrm{~h}$ do fosfato de zinco com cobre, que estatisticamente foi comprovado como insignificante, isto apenas confirma a resistência máxima de ambos os materiais no período de 1 hora para esta pesquisa, discordando dos trabalhos de BRANCO; HEGDAHL ${ }^{4}, 1983$, MONDELLI, MARTINS, STEAGALL, NAVARRO ${ }^{25}, 1994$.

Estes resultados apresentam bastante divergência com os constantes da literatura pois como citado anteriormente, a diferença dos materiais quanto à marca comercial, pode vir a ser um fator de variância entre as médias obtidas e, como na literatura o único material nacional que pode ser comparado com outros autores foi o 
fosfato de zinco. Para o cimento resinoso e o ionomérico fica a sugestão de novos trabalhos para melhor avaliação da qualidade desses cimentos nacionais.

Já para o fosfato de zinco de cobre, apenas um autor comparou a resistência desse tipo de material, não sendo porém o mesmo tipo utilizado nesta pesquisa. Por isso, não apresentou valores semelhantes, o que implica dizer que, trata-se de um material, apresentado ao mercado americano, de marca comercial mundialmente conhecida, mas sem trabalhos avaliando suas propriedades mecânicas; apresenta indicações para procedimentos de cimentação de peças protéticas e proteções pulpares, mas deve ser ainda extensamente pesquisado em outras situações de teste.

Para os resultados da resistência tração diametral, as médias obtidas quanto foram as mais baixas em relação aos outros testes mecânicos.

O cimento resinoso apresentou os valores mais altos de tração diametral, mas bem abaixo quando comparado ao cisalhamento e compressão axial. Mesmo assim, foi o único material que apresentou diferença estatisticamente significante, comprovando realmente que este cimento melhorou suas propriedades nos intervalos de 1 e $24 \mathrm{~h}$. Dessa forma pode-se afirmar que este cimento apresentou os melhores resultados nas três propriedades mecânicas analisadas nesses períodos, apontando valores semelhantes a outros artigos citados na literatura (LI; WHITE ${ }^{22}$, 1999, WHITE, YU44, 1993).

Convém salientar que somente a resistência mecânica não é suficientes para classificar como melhor um agente cimentante. Propriedades físicas, químicas e biológicas devem ser avaliadas para apontar a superioridade ou não de um agente cimentante em relação a outro.

Já para o cimento de ionômero de vidro analisado, nos três ensaios tiveram os valores mais baixos, o que confere com as propriedades mecânicas mais insatisfatórias em comparação a outros trabalhos que apresentaram valores similares,(GERDULLO; NAKAMURA; SUGA; NAVARRO ${ }^{16}$, 1995) e discordando de outros autores que apresentaram valores mais altos ( WHITE; YU ${ }^{44}, 1993$ ) .

Os fosfatos de zinco analisados nesta pesquisa se destacaram por apresentar melhores propriedades mecânicas que o cimento de ionômero de vidro e o destaque maior ficou por conta do fosfato de zinco com cobre, que apresentou resultados similares quanto a resistência à compressão e tração diametral e resultados superiores quanto à resistência ao cisalhamento. 
O que é válido afirmar é que o cimento resinoso é sem dúvida o melhor material quanto às resistências ao cisalhamento, à compressão e à tração diametral.

Fica, como sugestão, a realização de novas pesquisas com estes materiais fabricados em nosso pais, a fim de verificar se os resultados apresentamse satisfatórios e semelhantes a esta pesquisa, além de difundir o conhecimento do fosfato de zinco com cobre e avaliar se é válido adquirir este produto para o mercado consumidor brasileiro. 
CONCLUSÕES

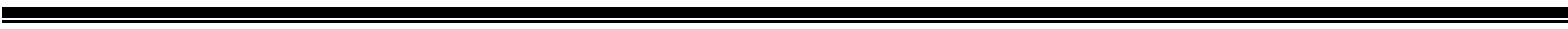



Esta pesquisa laboratorial com quatro tipos de agentes cimentantes analisados em dois períodos, (1 hora e 24 horas após a confecção dos espécimes) quanto a resistência ao cisalhamento, à compressão e à tração diametral possibilitou concluir:

\section{Propriedades Mecânicas}

$\checkmark$ O cimento resinoso "fill magic dual cement" apresentou as maiores médias para os três ensaios mecânicos realizados;

$\checkmark$ o cimento de ionômero de vidro "vitro cem" apresentou as menores médias nos três ensaios mecânicos realizados;

$\checkmark$ Os cimentos de fosfato de zinco e fosfato de zinco com cobre apresentaram resultados similares satisfatórios para os ensaios de compressão e tração diametral, com diferença apenas nas médias para o ensaio de cisalhamento, onde o fosfato de zinco com cobre apresentou melhor comportamento;

\section{Períodos}

$\checkmark$ No período de $1 \mathrm{~h}, \mathrm{o}$ cimento resinoso apresentou o maior valor médio e o cimento de ionômero de vidro o menor valor para o ensaio de cisalhamento;

$\checkmark$ No período de $24 \mathrm{~h}$, somente o cimento resinoso e o fosfato de zinco com cobre apresentaram resultados estatisticamente significantes em comparação ao período de $1 \mathrm{~h}$ para o ensaio de cisalhamento;

$\checkmark$ Para o ensaio de compressão, somente o cimento resinoso e o cimento de ionômero de vidro aumentaram a resistência, 
apresentando valores estatisticamente significantes com relação aos dois períodos analisados;

Todos os materiais atingiram a resistência mínima de compressão adotada pela ISO, mas apenas o cimento resinoso atingiu os valores de resistência mínima adotada pela ADA;

Para o ensaio de tração diametral, nos dois períodos analisados, somente o cimento resinoso obteve valores estatisticamente significantes, com os menores valores obtidos pelo cimento de ionômero de vidro; 
REFERÊNCIAS BIBLIOGRÁFICAS 



\section{REFERÊNCIAS BIBLIOGRÁFICAS}

1. Algera TK, CJ; Prahl-Andersen, B; Feilzer, AJ. The influence of environmental conditions on the material properties of setting glass-ionomer cements. Dent Mater. 2006 Set;22(9).

2. Anusavice K. Materiais Dentários. 11 ed ed. Rio de Janeiro; 2005.

3. Attar N, Tam LE, McComb D. Mechanical and physical properties of contemporary dental luting agents. J Prosthet Dent. 2003 Feb;89(2):127-34.

4. Branco R, Hegdahl T. Physical properties of some zinc phosphate and polycarboxylate cements. Acta Odontol Scand. 1983 Dec;41(6):349-53.

5. Carneiro FB, A. Resistance à la tractions des bétons. Rio de Janeiro: Instituto Nacional de Tecnologia; 1949.

6. Cefaly DF, EB; Mondelli, RFL; Francisconi, PAS; Navarro, MFL. Diametral tensile strength and water sorption of glass-ionomer cements used in atraumatic restorative treatment. J Appl Oral Sci. 2003;11(2):96-101.

7. Cefaly DV, FP; Seabra, BGM; Mondelli, RFL; Navarro, MFL. Effect of time on the diametral tensile strength of resin-modified restorative glass ionomer cements and compomer. Braz Dent J. 2001;12(3):201-4.

8. Charlton D. Current status of dental luting cements. [cited 2006 10/04/2006]; Available from: https://decs.nhgl.med.navy.mil/DMNOTES/cements.pdf

9. Ciarelli LE, AA; Navarro, MFL; Carvalho, RM. Punch shear strength of luting cements. Rev Fob. 2001 jan/jun;9(112):93-6.

10. Craig RG; Powers J. Materias Dentários Restauradores. 11 ed ed. São Paulo; 2004. 
11. de la Macorra JC, Pradies G. Conventional and adhesive luting cements. Clin Oral Investig. 2002 Dec;6(4):198-204.

12. Ergin S, Gemalmaz D. Retentive properties of five different luting cements on base and noble metal copings. J Prosthet Dent. 2002 Nov;88(5):491-7.

13. Fleming GJ, Marquis PM, Shortall AC. The influence of clinically induced variability on the distribution of compressive fracture strengths of a hand-mixed zinc phosphate dental cement. Dent Mater. 1999 Mar;15(2):87-97.

14. Foley JE, DJP; Lloyd, CH; Blackwell, A Black copper phosphate cement: does it have a future. Eur J Prosthodont Rest Dent. 2001;9(2):67-71.

15. Fraser $\mathrm{T}$. The impossible dream: a sterile field beneath modern day restorations. [cited 2006 16/04]; Available from: http://www.copalite.com/Fraser_Literature_Review.htm

16. Gerdullo MN, SCB; Suga, RS; Navarro, MFL. Resistência à compressão e à tração diametral de cimentos de ionômero de vidro indicados para cimentação. Rev Odontol Univ São Paulo. 1995;9(1):17-22.

17. Gorodovsky S, Zidan O. Retentive strength, disintegration, and marginal quality of luting cements. J Prosthet Dent. 1992 Aug;68(2):269-74.

18. Kleverlaan CJ, van Duinen RN, Feilzer AJ. Mechanical properties of glass ionomer cements affected by curing methods. Dent Mater. 2004 Jan;20(1):45-50.

19. Kumbuloglu O, Lassila LV, User A, Vallittu PK. A study of the physical and chemical properties of four resin composite luting cements. Int J Prosthodont. 2004 May-Jun;17(3):357-63.

20. Levartovsky SK, E; Georgescu, M; Goldstein, GR. A comparison of the diametral tensile strength, the flexural strength, and the compressive strength of two new core materials to a silver alloy-reinforced glass ionomer material. J Prosthet Dent. 1994 Nov;72:481-5. 
21. Lewis BA, Burgess JO, Gray SE. Mechanical properties of dental base materials. Am J Dent. 1992 Apr;5(2):69-72.

22. Li ZC, White SN. Mechanical properties of dental luting cements. J Prosthet Dent. 1999 May;81(5):597-609.

23. Martins L. Estudo de propriedades mecânicas (resistências ao cisalhamento por puncionamento, à compressão e à tração diametral) de 7 cimentos utilizados como base protetora de restaurações [Mestrado]. São Paulo: Faculdade de Odontologia de Bauru; 1986.

24. McComb D, Sirisko R, Brown J. Comparison of physical properties of commercial glass ionomer luting cements. J Can Dent Assoc. 1984 Sep;50(9):699701.

25. Mondelli JM, LRM; Steagall, L; Navarro, MFL. Resistência ao cisalhamento por puncionamento, compressão e tração diametral de cimentos utilizados como base protetora de restaurações. Rev Fob. 1994;2(1):1-6.

26. Mount GJ, Makinson OF, Peters MC. The strength of auto-cured and light-cured materials. The shear punch test. Aust Dent J. 1996 Apr;41(2):118-23.

27. Navarro MP, RC. Cimentos de Ionômero de Vidro. 1 ed ed. São Paulo; 1998.

28. Nicholson JW, McKenzie MA. The properties of polymerizable luting cements. J Oral Rehabil. 1999 Oct;26(10):767-74.

29. Nomoto R, Carrick TE, McCabe JF. Suitability of a shear punch test for dental restorative materials. Dent Mater. 2001 Sep;17(5):415-21.

30. Palma RN, MFL; Ishikiriama, $A$; Marangoni, $M H$. Resistência à compressão e à tração diametral de cimento de ionômero de vidro convencional e reforçado com metal. Rev Odontol Univ São Paulo. 1994;8(4):235-8. 
31. Piwowarczyk A, Lauer HC. Mechanical properties of luting cements after water storage. Oper Dent. 2003 Sep-Oct;28(5):535-42.

32. Platt JA. Resin cements: into the 21st century. Compend Contin Educ Dent. 1999 Dec;20(12):1173-6, 8, 80-2; quiz 84.

33. Powers JF, JW; Craig, RG. Modulus of elasticity and strength properties of dental cements. JADA. 1976 Mar;92:588-91.

34. Prakki AC, RM. Cimentos resinosos dual: características e considerações clínicas. PGR-Pós-Grad Rev Fac Odontol São José dos Campos. 2001 jan/abr;4(1):21-6.

35. Prentice LH, Tyas MJ, Burrow MF. The effect of mixing time on the handling and compressive strength of an encapsulated glass-ionomer cement. Dent Mater. 2005 Aug;21(8):704-8.

36. Rosenstiel SF, Land MF, Crispin BJ. Dental luting agents: A review of the current literature. J Prosthet Dent. 1998 Sep;80(3):280-301.

37. Roydhouse R. Punch-shear test for dental purposes. J Dent Res. 1969 jan;49(1):131-6.

38. Roydhouse RL, DR. Punch shear strengths of zinc phosphate cement and calcium hydroxide mixtures. J Can Dent Assoc. 1969;35(2):72-5.

39. Santos JF, Steagall L, Silveira JI. Punch shear strength of polycarboxylate cements. J Prosthet Dent. 1978 Apr;39(4):420-3.

40. Silva e Souza Jr. MC, RM; Mondelli, RFL; Franco, EB; Pinheiro, RF. Odontologia Estética fundamentos e aplicações clínicas. 1 ed ed. São Paulo; 2001.

41. Smith DC. Dental cements. Current status and future prospects. Dent Clin North Am. 1983 Oct;27(4):763-92. 
42. Smith DC, Cooper WE. The determination of shear strength. A method using a micro-punch apparatus. Br Dent J. 1971 Apr 20;130(8):333-7.

43. Vieira D. Propriedades dos Materiais Odontológicos. 1 ed ed. São Paulo; 1965.

44. White SN, Yu Z. Physical properties of fixed prosthodontic, resin composite luting agents. Int J Prosthodont. 1993 Jul-Aug;6(4):384-9.

45. White SN, Yu Z. Compressive and diametral tensile strengths of current adhesive luting agents. J Prosthet Dent. 1993 Jun;69(6):568-72.

46. Williams PD, Smith DC. Measurement of the tensile strength of dental restorative materials by use of a diametral compression test. J Dent Res. 1971 MarApr;50(2):436-42. 
ABSTRACT

=



ABSTRACT

\section{Evaluation of three dental cements of punch shear strength, axial compressive and diametral tensile}

The dental cements are used, routinely, to fixation of restorative dental and responsible for filling the interface between the tooth and a restoration, therefore they must present satisfactory mechanical properties, in order to support the masticatory forces and occlusal loads in the oral cavity. Being thus, the objective of this work was to evaluate four dental cements (a phosphate zinc, a red copper phosphate zinc, a glass-ionomer and a resin cement), in relation to the punch shear strength, axial and diametral compression strength. For the punch shear assay, had been made specimens in a matrix in ring form with dimensions of $14 \mathrm{~mm}$ of internal diameter and $1,5 \mathrm{~mm}$ of height that allowed to get a disc or currency of the materials with these dimensions which was connected in a proper device for the test. For the axial compressive assay had been followed the specifications of "ADA n $96^{\circ}$ " and "ISO 9917:1(E)" whose specimen is of cylindrical format with dimensions of $6 \mathrm{~mm}$ of height for $4 \mathrm{~mm}$ of diameter. The tensile diametral assay, not exactly presenting specific norms for dental cements, followed the dimensions of the specimen for the axial compressive assay. Ten specimens of each material for the respective assays, analyzed in the periods of 1 and 24 hours had been made. The results were statistically analyzed with the two-way ANOVA, followed of the comparative tukey test with $p<0,05$ The dental cement who obtained the highest values of strength was the resin cement for the three tests and the glass-ionomer cement obtained the lowest values of strength among all the materials and different periods.

Keywords: Mechanical properties. dental cements. strength test. 